\title{
Report on the Open Forum on Establishment of the National Council for Laboratory Accreditation (NACLA) at the National Institute of Standards and Technology January 7, 1997
}

Janice S. Jablonski

Editor

Walter G. Leight

Editor

U.S. DEPARTMENT OF COMMERCE

Technology Administration

National Institute of Standards and Technology

Gaithersburg, MD 20899-0001

2C

100 



\section{Report on the Open Forum on Establishment of the National Council for Laboratory Accreditation (NACLA) at the National Institute of Standards and Technology January 7, 1997}

Janice S. Jablonski

Editor

Walter G. Leight

Editor

U.S. DEPARTMENT OF COMMERCE

Technology Administration

National Institute of Standards

and Technology

Gaithersburg, MD 20899-0001

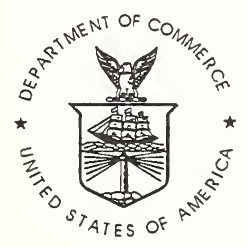

U.S. DEPARTMENT OF COMMERCE William M. Daley, Secretary

TECHNOLOGY ADMINISTRATION

Mary L. Good, Under Secretary for Technology

NATIONAL INSTITUTE OF STANDARDS

AND TECHNOLOGY

Robert E. Hebner, Acting Director 


\section{FOREWORD}

The following announcement for the open forum on establishment of the National Council for Laboratory Accreditation (NACLA), to be held at the National Institute of Standards and Technology, was distributed to thousands of potentially interested organizations and individuals. A program agenda was provided to encourage a broad cross-section of representatives to attend and participate in discussions. The issues to be addressed related to changing the U.S. multifaceted approach to laboratory accreditation and seeking support for a proposal to establish a public-private partnership for implementing a national system for laboratory accreditation with the goals of facilitating domestic commerce and achieving international acceptance of test data generated by laboratories in the United States.

\section{Announcement of the Open Forum \\ Tuesday, January 7,1997}

National Institute of Standards and Technology

\section{Open Forum on: \\ Establishment of the National Council for Laboratory Accreditation (NACLA)}

An open forum will be held at the National Institute of Standards and Technology on January 7 , 1997, to discuss the establishment of the National Council for Laboratory Accreditation (NACLA). NACLA is proposed as a cooperative partnership between the public and private sectors that provides for realization and implementation of a comprehensive U.S. laboratory accreditation infrastructure for national and international recognition and acceptance of accredited laboratory competence. It is envisioned as an organization with active participation by all affected interests: laboratories, accreditors, and those who require accreditation, both from industry and government.

NACLA will specify uniform procedures based on national and international standards and guides for organizations that accredit calibration and testing laboratories. National and international acceptance of their competency will be achieved through NACLA recognition. All parties of interest will benefit from widespread acceptance of the results of tests (performed only once) on a given product. This will eliminate the current duplication, reduce costs, and lead to one-stop shopping.

The meeting will provide a forum for discussion of the NACLA planning documents. It is intended to develop a consensus to establish NACLA as the unifying organization to meet national needs for laboratory accreditation. Presentations will include accreditation issues, background, and future organizational plans. Attendees are invited to discuss all aspects of the plans. 


\section{TABLE OF CONTENTS}

\section{Page}

ABSTRACT

vi

AGENDA

vii

PLENARY SESSION

Development of the NACLA Proposal 5

Stakeholder Breakout Sessions

STAKEHOLDER BREAKOUT SESSION REPORTS

Group 1 - Industry Representatives

Group 2 - Accrediting Body Representatives

Group 3 - Government Representatives

Group 4 - Laboratory Representatives

Group 5 - Industry Representatives 18

Group 6 - Laboratory Representatives 20

OPEN DISCUSSION AND NEXT STEPS

Open Discussion 25

Next Steps 27

Nominating Committee Report

APPENDIX A: $\quad$ Proposed Structure for the National Council for Laboratory Accreditation

APPENDIX B: $\quad$ Presentations

APPENDIX C: $\quad$ Final List of Participants

C-1

APPENDIX D:

NACLA Interim Board of Directors

D-1 


\section{ABSTRACT}

An Open Forum on Establishment of the National Council for Laboratory Accreditation (NACLA) was held at the National Institute of Standards and Technology (NIST), in Gaithersburg, Maryland on January 7,1997 . The forum was jointly sponsored by NIST, ACIL (formerly the American Council of Independent Laboratories), and the American National Standards Institute (ANSI). It was attended by more than 300 representatives from private industry and the government. The purpose of the Forum was to discuss a proposal to establish the National Council for Laboratory Accreditation (NACLA), which would be a cooperative partnership between the public and private sectors designed to provide a national infrastructure for laboratory accreditation in the United States. The agenda for the Forum included a keynote address by Dr. Mary Good, Under Secretary of Commerce for Technology, presentations on the history of the joint NIST/ANSI/ACIL effort to address the problems of laboratory accreditation in the United States and the development of the NACLA proposal, six stakeholder breakout sessions, an open discussion, a presentation of next steps to be taken toward the establishment of NACLA, and a presentation concerning the process for nominating an interim Board of Directors for NACLA.

The six stakeholder breakout sessions included two sessions each for industry and laboratory representatives, and one session each for accrediting bodies and government representatives. Each of the two-hour sessions addressed the following topics:

$>\quad$ How NACLA participation will benefit stakeholders;

$>\quad$ Potential disincentives or disadvantages to NACLA participation;

$>\quad$ Key strengths and weaknesses of the proposed NACLA organizational structure and operating functions;

$>\quad$ Key issues for NACLA to address; and

$>\quad$ The concept and composition of and Interim NACLA Board of Directors.

In the afternoon plenary session, a representative from each breakout session presented a report on the outcome of the group discussions.

The NACLA proposal included provisions for appointing an Interim Board of Directors for NACLA, consisting of four representatives from the laboratory community, four representatives from industry, four government representatives, three accrediting body representatives, and two general interest representatives. The proposal further suggested that the Interim Board be Chaired by a representative from NIST. Participants were encouraged to nominate prospective Board members, in writing, by February 7,1997. Final selection of the Interim Board was to be made by the Laboratory Accreditation Work Group (LAWG) Steering Committee on February 19, 1997. 


\begin{abstract}
AGENDA
Open Forum on Establishment of the National Council for Laboratory Accreditation
\end{abstract}

January 7, 1997

\title{
National Institute of Standards and Technology \\ Red Auditorium \\ Gaithersburg, Maryland
}

8:00 AM

8:45 AM

8:55 AM

9:00 AM

9:30 AM

9:45 AM

10:15 AM

10:30 AM

$10: 45$ AM

12:45 PM

1:45 PM

2:30 PM

3:15 PM

3:45 PM

4:15 PM
Registration

Welcome to NIST - Dr. Robert Hebner, NIST

Chairman's Opening Remarks, Mr. Sergio Mazza, ANSI

Keynote Address, Dr. Mary Good, Department of Commerce

Recapitulation of LAWG History - Mr. Joseph O'Neil, ACIL

NACLA Summary - Dr. Belinda Collins, NIST

Procedures for Breakout Sessions - Ms. Jan Jablonski, consultant

Break

Breakout Sessions

Lunch (NIST Cafeteria)

Reports from Breakout Sessions

Open Discussion - moderated by Mr. Sergio Mazza

Next Steps - Mr. Walter Leight, NIST

Nominating Committee Report - Mr. Joseph O'Neil

Concluding Remarks - Mr. Sergio Mazza 



\section{PLENARY SESSION}





\title{
OPEN FORUM ON ESTABLISHMENT OF THE NATIONAL COUNCIL FOR LABORATORY ACCREDITATION
}

\author{
January 7, 1997 \\ Plenary Session
}

An Open Forum on Establishment of the National Council for Laboratory Accreditation (NACLA) was held from 9:00 AM to 4:30 PM in the Red Auditorium at the National Institute for Standards and Technology (NIST), in Gaithersburg, Maryland. The forum was jointly sponsored by NIST, ACIL (formerly the American Council of Independent Laboratories), and the American National Standards Institute (ANSI). It was attended by more than 300 representatives from private industry and the government. Mr. Sergio Mazza, President of ANSI, served as Chairman of the forum.

Dr. Robert Hebner, Acting Deputy Director of NIST, welcomed the group to NIST and provided a brief overview of NIST programs. He stated that NIST hoped to achieve three objectives at the forum, which were to understand:

$>\quad$ How the private sector views the current laboratory accreditation system in
the United States; how it is working and how it should work in the future;
$>\quad$ What role NIST should play in the U.S. laboratory accreditation system; and
$>\quad \begin{aligned} & \text { Who the ultimate customers for laboratory accreditation are and what their } \\ & \text { needs are. }\end{aligned}$

He noted that NIST believes the forum is a very important step toward improving the system of laboratory accreditation in the United States.

In his opening remarks, Mr. Mazza reminded participants that the effort that led to the proposal for NACLA began over two and one-half years ago when NIST, ACIL and ANSI first met to address the need to coordinate laboratory accreditation in the United States. Mr. Mazza noted that five principal points have predominated in the subsequent discussions:
$>\quad$ International acceptance of test data generated in the United States is an important competitive issue;
$>\quad$ Domestic acceptance of U.S. test data is complicated by a patchwork of multiple accreditation systems;


$>\quad$ There is a general lack of confidence in U.S. accreditation systems in both the public and private sectors;

$>\quad$ There is a lack of widespread use of international standards as common baseline criteria by U.S. laboratory accreditation programs; and

$>\quad$ There is a compelling need to address these problems in a comprehensive and meaningful way.

Mr. Mazza stated that the purpose of the forum would be to focus attention on the concept of a national council for laboratory accreditation as an effective means for addressing these key points. His objective for the day was to find common ground over which all stakeholders can move forward together.

Dr. Mary Good, Under Secretary of Commerce for Technology, provided the Keynote Address. She noted the progress that has been made by the Laboratory Accreditation Working Group (LAWG) under the joint leadership of ANSI, ACIL and NIST. LAWG has made considerable progress in defining the problems associated with the existing laboratory accreditation system in the United States, understanding the needs of the ultimate users of laboratory accreditation, and developing a proposal for taking action to correct existing problems and to make the system more responsive to users.

Dr. Good noted that laboratory accreditation began as an initiative of the laboratory industry. They viewed accreditation as a means for distinguishing among laboratories on the basis of competency, and sought independent third party accreditation to weed out poor performers. In the early 1970's, she noted, the laboratory industry asked NIST to establish a laboratory accreditation program. Since then, NIST has been an accreditor. NIST's role changed when President Clinton signed the Technology Transfer and Advancement Act in March of 1996, giving NIST responsibility for coordinating conformity assessment activities in both the public and private sectors. Dr. Good emphasized NIST's role and stated that, consistent with that role, NIST's purpose in participating in the forum was to facilitate the development of a credible U.S. domestic system for laboratory accreditation that addresses both domestic and international trade issues. She stated the need for a workable system that will be recognized as competent by all those who require accreditation domestic and international agencies and industry. Dr. Good also noted that in order to work well, the U.S. laboratory accreditation system must allow manufacturers and other users to be confident that test data are generated by qualified laboratories using valid test methods and reliable operating procedures. The system must also allow governments at all levels within the United States to be confident that test data used to demonstrate regulatory compliance or conformance to purchasing specifications are valid and reliable.

In closing, Dr. Good reminded participants that in October 1995, at a previous open forum on laboratory accreditation, a consensus emerged on the following points: 
$>\quad$ Use of international standards should be the basis for reciprocity among laboratory accreditation programs in the United States;

$>\quad$ There should be international acceptance of the U.S. system;

$>\quad$ High-quality accreditation and sound laboratory data must be preserved;

$>\quad$ Greater education of users is needed;

$>$ Government programs involving laboratory accreditation need to be coordinated; and

$>\quad$ The common goals and interests of government and industry in this area should be explored.

She noted that the LAWG proposal for the NACLA infrastructure would address all of these objectives and that she expected sufficient ground work to be laid by the end of the forum to move toward establishment of NACLA.

\section{Development of the NACLA Proposal}

Mr. Joe O'Neil, President of ACIL, provided a brief historical summary of the activities of the Laboratory Accreditation Working Group (LAWG). He highlighted the following milestones, which led to the development of the proposed NACLA structure:

$>\quad$ May 17, 1994: the first meeting of ANSI, ACIL, and NIST was held to discuss the status of laboratory accreditation in the United States.

$>\quad$ August 22, 1994: the first open meeting of the NIST/ANSI/ACIL publicprivate partnership on laboratory accreditation was held, attended by approximately 50 representatives from industry, the laboratory community, accrediting bodies, standard-setting organizations, and government.

$>\quad$ Fall of 1994: LAWG Task Groups representing manufacturers, laboratories, accreditors, government organizations, and international concerns gathered interested individuals to discuss laboratory accreditation issues.

$>\quad$ December, 1994: the LAWG Task Group Co-Chairs met to report on the results of their task group discussions.

$>\quad$ January, 1995: the first meeting of the LAWG Steering Committee was held. The Steering Committee included representatives from the government, laboratories, industry, standard-setting organizations, and accrediting bodies. 
$>\quad$ February 22, 1995: the National Research Council published its report entitled: "Standards Conformity Assessment and Trade Into the Twenty-First Century," which affirms the need for improvements in the U.S. system for conformity assessment, including laboratory accreditation.

$>\quad$ Summer, 1995: the LAWG Steering Committee and Task Groups developed their vision for the U.S. laboratory accreditation system:

"A U.S. laboratory accreditation system that includes a cooperative relationship among the public and private sectors and that achieves:

For the testing laboratory, a single accreditation in a given field of testing with world wide recognition of the laboratory's competence.

For the user, a test performed once with world wide acceptance."

$>\quad$ October 13, 1995: NIST, ANSI, and ACIL jointly sponsored an open forum on laboratory accreditation.

$>\quad$ March, 1996: the Technology Transfer and Advancement Act was enacted, giving NIST responsibility for coordinating conformity assessment in the United States.

$>\quad$ April, 1996: the LAWG Steering Committee generated its first draft concept paper on NACLA and its operating functions.

$>\quad$ November, 1996: the LAWG Steering Committee finalized its concept paper on the proposed structure and operating functions of NACLA for presentation at the 1997 open forum.

Dr. Belinda Collins, Director of the Office of Standards Services at NIST, presented an overview of the proposed NACLA concept. For purposes of background, Dr. Collins reminded participants of some of the problems with the current U.S. system of laboratory accreditation. For example, she noted that individual laboratories pay an estimated $\$ 10$ thousand to $\$ 50$ thousand annually for laboratory accreditations and that there are more than 150 accrediting bodies in the United States, the majority of which do not recognize each others' accreditations. At the Federal, state, and local levels of government, laboratory accreditations are sector-specific, with no formal or other means of extending reciprocity and little or no coordination among programs.

She noted that a national system for laboratory accreditation, such as the NACLA proposal, offers an opportunity to achieve a coordinated, cost-effective system that is built on a consensus approach. Dr. Collins also noted that the proposed structure for NACLA represents a public-private 
partnership which will allow for all viewpoints to be heard. She reviewed the guiding principles that formed the basis for NACLA, which include:

$>\quad$ NACLA must be a formally chartered, identifiable private sector body with government participation;

$>\quad$ NACLA must be able to realize the vision of universal acceptability of test results by competent laboratories accredited by NACLA-recognized accreditors;

$>\quad$ NACLA must implement a comprehensive and rigorous domestic system for laboratory accreditation;

$>\quad$ NACLA must use widely recognized international standards and guides as the basis for its standards and procedures; and

$>\quad$ NACLA must implement a system for recognizing competent accreditors based on rigorous, uniformly applied standards.

Dr. Collins stated that agreement among all stakeholders will be the key to NACLA's success. To accomplish this goal, NACLA will have to allow for diversity in laboratory accreditation programs while implementing a system that reduces the overlap and duplication in the current system.

Dr. Collins stated that NACLA should include members from both the private and public sectors. Membership should be voluntary and open to anyone who subscribes to the NACLA vision, principles, and protocols. The LAWG proposal calls for establishment of a Board of Directors with governing and policy making responsibilities. NACLA's operating functions would focus initially on development of standards for assessing accrediting bodies. In the future, NACLA would serve as the U.S. focal point for laboratory accreditation and would develop and represent U.S. positions on laboratory accreditation within the international community.

\section{Stakeholder Breakout Sessions}

Six stakeholder breakout sessions were organized, each facilitated by a member of the LAWG Steering Committee, as follows:

$>\quad$ Group 1 - Industry Representatives, led by Mr. Lou Dixon of the Ford Motor Company;

$>\quad$ Group 2 - Accrediting Body Representatives, led by Mr. Peter Unger of the American Association for Laboratory Accreditation (A2LA); 
$>\quad$ Group 3 - Government Representatives, led by Mr. Richard Baldwin of the U.S. Food and Drug Administration;

$>\quad$ Group 4 - Laboratory Representatives, led by Ms. Lynne Neumann of Entela, Inc.;

$>\quad$ Group 5 - Industry Representatives, led by Ms. Kim Phillipi, of Entela, Inc.; and

$>\quad$ Group 6 - Laboratory Representatives, led by Mr. David Krashes of the MMR Group, Inc.

Each of the two-hour breakout sessions addressed the following topics:

$>\quad$ How NACLA participation will benefit the stakeholders.

$>\quad$ Potential disincentives or disadvantages to NACLA participation.

$>\quad$ Key strengths and weaknesses of the proposed NACLA organizational structure and operating functions.

$>\quad$ Key issues for NACLA to address.

$>\quad$ The concept and composition of an Interim NACLA Board of Directors.

In the plenary session which followed the breakout sessions, a representative from each group presented a report on the outcomes of group discussions. 
STAKEHOLDER BREAKOUT SESSION REPORTS 



\title{
OPEN FORUM ON ESTABLISHMENT OF THE NATIONAL COUNCIL FOR LABORATORY ACCREDITATION
}

\author{
January 7, 1997
}

\section{Stakeholder Breakout Session Reports}

\section{Group 1 - Industry Representatives}

Report presented by: Mr. Lou Dixon, Ford Motor Company

1. Stakeholder Benefits

- Reduce costs from laboratories to manufacturers and customers

- Reduce number of audits

- Lower administrative costs

- Faster time to market

- Facilitate Mutual Recognition Agreements (MRAs)

- Level U.S. and international playing field

- Mutual recognition of test results among participants

2. Disincentives/Disadvantages

- Fewer accrediting bodies

- "Downsize" state/local accrediting agencies

- Additional fees (will industry get what they pay for?)

- Voluntary vs. mandatory program

3. Strengths/Weaknesses

Strengths:

- Government authority if full participation

- Uniform evaluating system for accreditors

- Industry participation

- Diversity of participants

- Board of Directors to include international perspective

Weaknesses:

- Overlap between NACLA and NELAC

- Larger groups make consensus more difficult

- Unspecified size of committees 
4. Key Issues

- Power of enforcement

- Lowest common denominator or impossible high standards for accreditation (need to develop workable standards)

- Regulatory authorities must participate

- Participate in the review and revision of OMB Circular A-119

- Transparent and open participation

- Anti-trust (accreditors)

- Mutual acceptability internationally

- Accelerate process to facilitate commerce

- Exclusion of non-U.S. entities

- Consider existing models

\section{Group 2 - Accrediting Body Representatives}

Report presented by: Mr. Peter Unger, A2LA

Mr. Fred Grunder, American Industrial Hygiene Association (AlHA)

Mr. C. E. Ramani, ICBO Evaluation Services

Benefits:

- International recognition

- Standardization

- Improved quality of accreditation systems

- Proficiency testing improvements

- Credibility

- One umbrella

- Reciprocity

- Consistency

- Self-regulation

- Technical competence of laboratories

- Greater value to laboratory customers

- Minimize proliferation

- Simplified mechanism

Disadvantages:

- Surrender of autonomy

- Some may go out of business

- Costs (laboratories/accreditors)

- Additional requirements to meet

- Dilution of quality 
- Liability

- Time

- Forced change

Strengths:

- Flexibility

- Uniformity

- Broad-based support

- Voluntary

- Increased credibility

- Public participation

- Breadth and generality

- NIST umbrella

- Increased authority

Weaknesses:

- Flexibility

- Bureaucracy

- Implementation

- Lack of authority (Federal mandate)

- Cost

- Lack of participation by Federal agencies

- Response time

- Lack of permanent staff

- Small organization participation

- Lack of stakeholder checks and balances

Key Issues:

- Implementation/obstacles

- Acceptability of program

- Recognition

- Process vs. diversity

- Horizontal vs. vertical

- Anti-trust

- Authority/legislation

- Standardization issues

- Training and education

- Cost

- Liability 
Composition of Board:

Three groups with equal representation:

- Accreditors

- Laboratories

- Users

Government and non-government representatives for all three groups

Operations Committee:

- Composition

- Process (most important)

- Several models exist (e.g., EAL/APLAC, CLIA, NVCASE)

\section{Group 3 - Government Representatives}

Report presented by: Mr. Richard Baldwin, U.S. Food and Drug Administration

1. Statement of support for NACLA.

- Lukewarm, mixed (because it is a lofty goal, much detail yet to be developed)

- Support in principle -- but need more specific detail on process

- Have not yet outlined a mechanism to assure acceptance of each others' processes and accreditations

- Need many more meetings (confidence building, exchange of documents, and commitment that this is worth doing)

- Weaknesses need to be addressed in detail

- The international arena is going to force U.S. action on the issue (an EAL/NACLA agreement would have tremendous force)

- Congress at this point is asking us nicely to do this (it could become more forceful if there is not internal U.S. cooperation to act)

- Need a strategy to get "head of agency" support (e.g., Mary Good to convene such a group, then get top-level agency support and buy-in)

- "Conditional love" at this point -- agencies must get more details and then determine their intent for participation

2. What are the advantages / disadvantages to NACLA participation?

Advantages:

- Consumer baseline for accreditation procedures 
- Standardization, reciprocity

- Fewer regulatory interactions

- Less financial resource utilization

- Promotes commerce and decreases cost of commerce

- Increase quality of testing and calibration data

- Less governmental intrusion (privatization)

- Get rid of poor labs through increased competition/quality

- Increase public safety

- Simplify requirements, decrease duplication, leading to better compliance

- Better compatibility between products

- Decrease non-tariff trade barriers, foster commerce

- Give a stronger voice internationally in standards development (i.e., better coordination of U.S. input)

- Bringing together diverse interests in a powerful way (i.e., greater voice)

- Increase U.S. government input into international standards

- Decrease duplicity

- Facilitates the introduction of new technology (i.e., increase ease of new technology approval) - also technology transfer

- Give U.S. trade negotiators a bargaining chip

- Generally facilitates internal interactions on all fronts - trade, negotiations (both dialog and interactions)

Disadvantages:

- Conflict with statutory and regulatory requirements of regulatory agencies (statutory requirements and regulations may be in conflict with NACLA standards, leading to potential diminished authority of regulatory agencies and delegation of authority to nonregulatory entities -- e.g., delegated test methods)

- Single accreditation may be too simplistic (there are multiple test methods for different attributes, also multiple audits are conducted for a broad range of sectors within single lab facilities)

- NACLA will need to hold accreditors to the same technical standards for very different types of laboratories

- International standards as bases may lead to variability of interpretations

- Potential NACLA liability for faulty test data

- NACLA will potentially be in the middle of conflicts over jurisdiction

- Need for specific accreditation and test standards (NACLA needs to specify tests and methods, also accreditation for specific test methods)

- Could be another level of bureaucracy

- Voluntary or mandatory -- potential problems either way

- May force U.S. regulators to accept reciprocity before we are ready (i.e., before everyone plays fairly or before there is a level playing field) 
3. Proposed NACLA organizational structure and operational functions:

\section{Strengths}

- Allows participation at all levels (including internationally)

- Promotes uniformity of standards

- Makes an attempt to achieve cooperation among stakeholders

\section{$\underline{\text { Weaknesses }}$}

- Accountability/coordination role outlined in law is ambiguous

- Limited to accreditation against international standards vs. national standards

- U.S. standards are law, have implications for manufacturer liability

- What are the international standards and who recognizes them?

- Need procedure for arriving at consensus

- Political change may move more rapidly than the bureaucracy of NACLA (ability to provide continuity to keep pace with rapid political change)

- Proposed structure does not provide a mechanism for achieving consensus among diverse perspectives (stakeholders) on issues of common interest

4. Recommendations:

- Get the interest groups together to communicate ideas and concerns to each other

- Need to build trust among the stakeholders

- Recognize that internationally, we are behind the power curve (the international arena is forcing U.S. action on this issue)

- Need to better understand the international support for NACLA

5. The concept and composition of the NACLA Interim Board:

- Look at the existing 150 accrediting bodies $\Rightarrow$ see what sectors are represented

- Needs to be a combination of stakeholders and sectors

- Maintain a link between standards developers and accreditors

- Size $\Rightarrow 15$ to 18 members ( $3-5$ being federal/state government representatives)

- Chair should be NIST (high-level management)

- Self-nomination process open to all stakeholders

- Members should be familiar with ISO Guides 58 and 25, and should thoroughly understand $\left(360^{\circ} /\right.$ top to bottom) the accreditation process

- LAWG selects the Interim Board, but NACLA membership should select permanent board members

- Look for consensus and ownership on the board

- Membership on the board is a WORKING commitment (lots to do quickly) 
6. Key issues that need to be addressed by NACLA:

- NACLA needs to established good liaison with existing groups

- Need to flush out issues of jurisdiction and authority

- How to determine frequency and length of accreditation.

- Accreditation scheme needs to accommodate diversity. (i.e., the process needs to accommodate the variety of activities that take place within a single laboratory)

- NACLA needs to be cognizant of the existing diversity among and within laboratories, and coordination needs to be situational to individual issues

- Practical application of international guidelines and standards (the outcome must lead to credible results and high quality products)

- Money speaks (perceived loss of fees from accreditation/licensing activities)

- How to actually achieve U.S. government reciprocity

- What to do if international standards are lower than U.S. standards

- Need confidence-building within the U.S. regarding laboratory accreditation (i.e., what do we mean by accreditation, and what do we expect? -- the requirements in ISO Guide 25 are very basic)

- Legal aspects of voluntary versus mandatory participation (can the government hold contractors to this process if it is a voluntary system?)

- Issue of a national mark (like a CE mark) -- will NACLA have one?

- How will NACLA be funded (i.e., the nature of funding)? -- membership fee, etc.? (NIST is willing to provide a secretariat on an interim basis, but ultimately NACLA needs to be self-sustaining, and costs/fees need to remain low)

- NACLA needs to develop "recognition criteria" (similar to ISO Guide 58) to recognize accreditors

- What are the incentives and mechanisms to realize NACLA's objectives (need more detail on process)?

- How is NACLA going to bring stakeholders together, regardless of who they are?

- How does NACLA assure the technical expertise of their technical auditors?

- Need to develop similarity of requirements for sector groups

- NACLA needs to explain the details, and facilitate further discussion among those with common interests

- How to handle privileged information of independent and industry laboratories (confidentiality issues)

- How will NACLA handle dishonesty, fraud, etc. (enforcement issues)?

- What is an accrediting body?

\section{Group 4 - Laboratory Representatives}

Report presented by: Ms. Lynne Neumann, Entela, Inc.

1. Benefits to Laboratories 
- Eliminate multiple accreditation

- International and national recognition

- Meaningful accreditation status

- Reduce artificial trade barriers

- Increase productivity

2. Potential Disadvantages

- Additional levels of cost and bureaucracy

- Coordinating groups

- Timeliness of goals (how quickly can this be achieved?)

- Forced to accept standards which do not meet our minimum quality level

- Funding

- "Flavor of the Month" managements

3. Key Strengths and Weaknesses

- Volunteer participation

- Conflicts of interest

- Key contact for recognition of U.S. system

- What are the incentives for accreditation bodies to become participants?

- How are QC, product certification, and data validation to be addressed?

4. General Concerns

- Develop trust and confidence between accreditors

- Marketability of accreditation

- Value to laboratories

- Expand the number of accreditation bodies (increased competition)

- Structure to gain authority

- NACLA assessor validation

- International and domestic acceptance

- NACLA should not be an accreditor of laboratories

- Address reciprocity

\section{Group 5 - Industry Representatives}

Report presented by: Mr. Gerald Ritterbusch, Caterpillar, Inc.

1. Benefits to Industry

- High quality data that are comparable

- Common standards, guidelines, and procedures for audits 
- NACLA will be a forum for discussion

- Want test data to be accepted by other bodies (domestic and international)

- Improve government confidence in laboratories and laboratory data

- NACLA will provide guidance for and demand consistency in audits

2. Disincentives/Disadvantages

- Laboratories may experience changes in market share - they must recognize that their market can be increased by wider acceptance of test data

- Additional level of accreditation without it being mandated. Is there an incentive to participate?

- Agreement on the definition of "good"

- NACLA lacks enough detail for understanding all of the issues. Could it create a wider disparity between laboratories?

3. Strengths Weaknesses

\section{Strengths}

- Compactness - Board and 2 committees

- Stakeholders have opportunity to participate in shaping the outcome

- Single operations committee to produce common interpretations

\section{Weaknesses}

- No link to international accreditations

- No defined link to NVCASE

- Not all encompassing in conformity assessment (product certification)

- Need milestones for further steps in the total conformity assessment world (standards and listing agencies)

- Need to know what it will look like when mature

4. Key Issues to Be Addressed

- Stakeholders must fully participate

- Need to market those who will realize benefits

- Government agency participation

- How does NACLA make sure that their program produces reciprocity with accreditors and laboratories?

- Expedite operation to ensure no new intervention by Congress or government agencies

- Must ensure that data from laboratories are comparable

- Adequate funding for viability 
5. NACLA Board of Directors Issues

- International liaison

- Use existing models/systems for harmonization

- Government agency participation: (EPA, FDA, FA, OSHA, FCC, HUD, DOE, CDC)

\section{Group 6 - Laboratory Representatives}

Report presented by: Mr. David Krashes, MMR Group, Inc.

1. Benefits to Laboratories

- Avoid multiple audits

- Accreditation will be respected worldwide

- Accreditation based on one standard

- Save money

2. Potential Disincentives or Disadvantages

- Don't want a bureaucracy

- Solving international problems before domestic problems

3. Strengths and Weaknesses

Strengths

- Will be good for laboratories (almost unanimous)

- Everybody pulls together

\section{$\underline{\text { Weaknesses }}$}

- Environmental laboratories are split off

- NIST has NVLAP

- If government agency (Federal or state) doesn't have to comply, it won't

- No time line established for NACLA to start approvals

- No "hammer" to force compliance with NACLA

4. Key Issues for NACLA to Address

- Lack of a government directive or law to mandate implementation

- Industry acceptance of NACLA

- Getting accrediting bodies to agree on one standard

- Obtaining effective and meaningful input from the laboratory community 
- Establishing reasonable costs

- Timely implementation

- $2 / 3$ believe the problem is domestic; $1 / 3$ believe the problem is international

- Will laboratories have access to NACLA's ratings of accreditors?

- NACLA must do the job well enough to ensure that all accreditors are credible

5. Other Recommendations

- Moderate annual dues are acceptable

- There must be a way to achieve reciprocity (both by accreditors and laboratory users) 



\section{OPEN DISCUSSION AND NEXT STEPS}





\title{
OPEN FORUM ON ESTABLISHMENT OF THE NATIONAL COUNCIL FOR LABORATORY ACCREDITATION
}

\author{
January 7, 1997 \\ Open Discussion and Next Steps
}

\section{Open Discussion}

Following the presentation of reports from the stakeholder breakout sessions, Mr. Mazza invited participants to ask questions or make comments on the issues presented. Questions were addressed by a panel consisting of Mr. Mazza, Dr. Collins and the group leaders. A summary of the questions, comments and responses follows.

Comment: Mr. Howard Forman, an attorney who specializes in alternative dispute resolution, encouraged the NACLA Interim Board to consider using alternative dispute resolution techniques to resolve conflicts as they arise in the process of establishing NACLA.

Question: Mr. Leonard Frier, of Met Laboratories, Inc., asked whether NACLA would be an accreditor of accrediting bodies or a coordinator of accrediting bodies.

Mr. Mazza responded that NACLA is not intended to be "super accreditor." Instead, NACLA would employ a peer review process which will allow accrediting bodies in the United States to recognize each others' work.

Comment: Mr. Ross Hansen, Quality Assurance Manager for Retlif Laboratories, stated that laboratory representatives have contended strongly that the laboratory community does not welcome an additional layer of accreditation bureaucracy. He further suggested that NACLA implementation go forward with a sunset clause that would call for the activity to stop if some or all of its goals are not accomplished in 18 to 24 months. Mr. Hansen also stated that he believes NACLA should focus on addressing domestic issues related to laboratory accreditation as its first priority.

In response, Mr. Mazza noted that government representatives agreed in their breakout session that issues of international recognition are likely to be an important factor motivating participation in NACLA by regulatory agencies.

Comment: Ms. Joanne Wilson of Lucent Technologies, stated that the proposed operating function for NACLA will make it an accreditor of accrediting bodies.

Mr. Unger stated in response that NACLA, like numerous similar European organizations, will have both a coordinating (horizontal) and an oversight (vertical) function to fulfill. Mr. Mazza noted that this has been an important issue for the LAWG Steering Committee for some time. He further stated that, in order to achieve international recognition, NACLA will have to recognize accreditor competency. 
Question: Mr. Joseph Cotruvo, of NSF International, asked the panel what incentives they see for accrediting bodies to reach consensus on an accreditation standard and process.

In response, Mr. Unger stated that accrediting bodies maintain an interest in NACLA in order to respond to the concerns of their clients: laboratories interested in reducing redundance and overlap in accreditation. Mr. Mazza agreed that much of the motivation for LAWG came out of a recognition by accreditors that they needed to respond to the demands of their market place. Mr. Dixon noted that industry representatives also have expressed a strong desire for a reliable accreditation system on which manufacturers can rely, instead of qualifying laboratories themselves.

Comment: Mr. John Locke, former President of A2LA, described the process by which the EAL grants accreditations, using a group of peer reviewers to assess accreditors and make a recommendation to the governing body of EAL.

Comment: Ms. Deborah Rade of Underwriters Laboratories, stated that she does not believe that a significant case has been made for establishing NACLA, and that further work should be done to demonstrate its potential benefit to the American public and to public safety, before proceeding with implementation.

Mr. Krashes noted that, within his breakout group, there was virtually unanimous agreement that NACLA would be beneficial.

Ms. Rade further stated that it has not been demonstrated that NACLA is the appropriate organization to address the problems that have been identified. She suggested that a better approach would be to allow Congress to provide a statutory mandate for NACLA, or a similar organization, through Federal legislation. In response, Mr. Mazza noted that Congress has already provided a gentle prod in the form of the Technology Transfer and Advancement Act of 1996, which requires NIST to coordinate conformity assessment in the United States. He further stated that, consistent with that statutory mandate, NACLA is intended to be a forum that brings together all stakeholders for purposes of agreeing on reasonable solutions to the problems we have identified.

Comment: Mr. George Marinenko of Waste Policy Institute noted, in response to Ms. Rade, that unanimous agreement is not necessary to establish the consensus opinion that NACLA should proceed. Rather, he stated, a majority is sufficient to indicate consensus.

Mr. Krashes stated that he was willing to stand and be counted as being in favor of NACLA and stated that others in the room were welcome to stand with him (whereupon a large majority of meeting participants stood and applauded to show their agreement that NACLA should proceed).

Question: Mr. Thomas Wiand of Hart Scientific, noted that calibration laboratories have a unique set of concerns related to laboratory accreditation, which differ from those of the testing laboratory 
community. He asked the panel whether they would agree to establish a separate delegation or group to represent calibration laboratories.

In response, both Dr. Collins and Ms. Neumann agreed that the perspectives of the calibration laboratory community are both unique and important to NACLA and that input from a calibration laboratory delegation would be welcome.

Comment: Mr. Troy Stallard, President of Standards Laboratories, Inc. and Chairman of ACIL, stated that ACIL believes that the only real alternative that we have today is for a single accreditation system such as NACLA. He further stated that ACIL endorses NACLA and would like to see it go forward.

Comment: Mr. Ed Nemeroff, Vice President of the National Conference of Standards Laboratories, stated that he and NCSL President, Mr. Kevin Ruhl, would request that the NCSL Board of Directors appoint a delegation from its membership to be an active part of NACLA.

\section{Next Steps}

Mr. Walter Leight, Deputy Director of the Office of Standards Services at NIST, provided a brief summary of the next steps to be taken by the LAWG Steering Committee, as follows:

$>\quad$ A report on the proceedings of the open forum will be prepared and distributed.

$>\quad$ Nominations for the NACLA Interim Board of Directors will be accepted until February 7, 1997.

$>\quad$ The nominating committee (established by the LAWG Steering Committee) will review the nominations and present a slate of nominees to the LAWG Steering Committee at its next meeting on February 19, 1997.

$>\quad$ At that meeting, the LAWG Steering Committee will elect the NACLA Interim Board and appoint a Chair for the Board.

$>\quad$ At the close of its meeting on February 19, the LAWG Steering Committee will cease its functions.

$>\quad$ The Chair of the NACLA Interim Board of Directors will convene the first meeting of the Board with staff support offered by NIST.

$>\quad$ The Interim Board will meet to appoint committees, devise procedures and prepare for permanent establishment of NACLA. 
$>\quad$ At the conclusion of its work, the Interim Board will present its recommendations to the potential membership of NACLA at another open forum.

Mr. Leight stated that nominations for the Interim Board should be forwarded to Mr. Joe O'Neil of ACIL.

\section{Nominating Committee Report}

Mr. O'Neil gave a brief overview of the process for establishing the NACLA Interim Board of Directors. He stated that the slate of nominees will be developed and presented by the Nominating Committee established by the LAWG Steering Committee in the Fall of 1996. Members of the Committee include Mr. O'Neil, Mr. Leight, and Mr. John Locke. Mr. O'Neil noted that their assignment was to nominate a group of people qualified to address all of the issues discussed at this and the previous forum. He further stated that, at the conclusion of its work, the Interim Board will present its proposed by-laws, procedures, practices, and committee structure for NACLA.

Mr. O'Neil stated that, at its meeting in December of 1996, the LAWG Steering Committee agreed to appoint an Interim Board of 18 members with:

$$
\begin{aligned}
& >\quad \text { Four laboratory representatives; } \\
& >\quad \text { Four industry representatives; } \\
& >\quad \text { Four government representatives; } \\
& >\quad \text { Three representatives from accrediting bodies; and } \\
& >\quad \text { Two general interest representatives. }
\end{aligned}
$$

The Steering Committee also agreed that the Chair of the Interim Board should be Dr. Belinda Collins, Director of NIST's Office of Standards Services. He noted that Dr. Collins' appointment as Chair signifies the Steering Committee's belief that it is important to have the visible leadership of NIST continue in this effort.

Mr. O'Neil reiterated that nominations for the Interim Board will close on February 7, 1997 and that all nominations should be mailed or faxed to him at ACIL. He asked that people who are nominated be qualified to address the issues before the Board and that they be willing to commit to participating in three to four meetings during the coming year and to do some work on NACLA issues between meetings. He noted that NIST provided forms for nominations which show his address and fax number and encouraged participants to make nominations as soon as possible. 
At the completion of Mr. O'Neil's presentation, Mr. Mazza thanked the participants for their efforts and declared the open forum adjourned. 



\section{APPENDIX A}

Proposed Structure for the National Council for Laboratory Accreditation 


ACCREDITATION" (NACLA)

The National Council for Laboratory Accreditation (NACLA) is made up of those in the United States who actively support development of a system for recognizing the competence of testing and calibration laboratories, and worldwide acceptance of their test and calibration reports.

\section{Background}

Since 1994, ACIL (formerly the American Council of Independent Laboratories), the American National Standards Institute (ANSI), and the National Institute of Standards and Technology (NIST) have sponsored an informal Laboratory Accreditation Working Group (LAWG) to examine issues related to laboratory accreditation and recognition in the United States, and to suggest solutions aimed at developing a system for the United States. Concerned with multiple, duplicate assessments and the lack of domestic or international recognition of accreditations, the group explored solutions which could lead the United States toward the goal of one assessment per laboratory in a given field of testing (testing includes calibration for the purposes of this notice), using internationally accepted procedures that can be accepted by all who require (or need) laboratory accreditation. Development of a credible domestic system for laboratory accreditation must be compatible with international systems so that international recognition of the U.S. efforts is achievable. LAWG solicited input and participation from all players in the process: laboratories, accreditors, industry, and government (Federal, state and local), as well as input from those concerned with international trade issues. The working group agreed on a vision and principles for a system, and identified the needs and desires of the key players, as follows:

- Manufacturers and other users must be confident that the test data from suppliers are generated by qualified laboratories that perform the testing according to valid test methods and which follow appropriate operating procedures.

- Governments at all levels within the United States must be confident that laboratory test data used to demonstrate compliance with regulations or procurement actions are generated by qualified test laboratories using valid methods and procedures.

- Laboratories need a single, consistently-applied mechanism for demonstrating their competence in generating test data and for evaluating their quality assurance procedures, with no duplication of valid assessments.

Governments, industry and other users of laboratory test data in the United States need a mechanism for ensuring their confidence in the laboratory test data supplied to demonstrate compliance with their procurement actions, regulations, or standards.

Foreign governments also need a means for obtaining recognition of the competence of U.S. laboratory data. The global market requires that laboratory accreditation procedures used on all sides of a trading relationship be similar, transparent, readily available, and based on international performance guides for their performance. Additional procedures may be needed to ensure recognition of the competence of an accreditation done by a particular body. 
Government, industry and other users require a mechanism for recognizing the competence of different laboratory accreditation bodies, while competent accreditation bodies require a level playing field where their accreditations are reciprocally accepted across political boundaries.

On October 13, 1995, an open Forum (see, Proceedings of the Open Forum on Laboratory Accreditation, October 13, 1995, NIST Special Publication 902, 1996) was held to discuss these issues and provide suggestions for solving the problems. During the Forum, consensus emerged on a vision to reduce the problems with the current "system." There was agreement that: international standards should serve as a basis for accreditation and recognition; reciprocity of competent accreditations in the United States is needed; there should be international acceptance of an effective U.S. system; high-quality accreditation and sound laboratory data must be preserved; greater education of users is needed; regulators at all levels (Federal, state, and local) must coordinate among themselves; and that common interest and goals between government and industry must be explored.

\section{Making the Vision a Reality}

During the Forum, there was consensus that a single public/private entity to coordinate laboratory accreditation activities within the United States is a reasonable solution. It would allow the needs of the various interest groups to be met, while allowing for competition among accreditors, governmental recognition, and international acceptance. This entity would develop common agreement on procedures for both accreditation and reciprocity of accreditation by all parties. The consensus approach used by standards developers in the country would provide for participation of interested and affected parties in the development of these procedures, and is a central element for the proposed system.

The proposed public/private entity, provisionally entitled the National Council for Laboratory Accreditation (NACLA), is envisioned as a formal arrangement among affected parties who agree on operational procedures. To be effective, NACLA must:

1. Agree on and adopt procedures for "recognizing" or "accepting" the competence of these accreditations, again using international guides.

a. Agree on and adopt procedures for accreditation of testing and calibration laboratories, using the international guides as a starting point.

b. Ensure procedures for withdrawing an accreditation or recognition.

2. Provide means for meeting specific Federal regulatory needs, while providing for regulatory recognition of those who meet these needs in their accreditation process.

3. Agree on and adopt procedures for internal operations.

4. Develop formally constituted basis for NACLA establishment and conduct for assuring that NACLA recognition follows appropriate procedures.

5. Work toward an infrastructure in which accreditors recognized as competent by NACLA can be considered for acceptance for both domestic and international requirements. NACLA will:

a. Address domestic issues and work to build a system which meets domestic needs and which is compatible with international systems.

b. Coordinate the U.S. positions for regional and international activities such as the 
International Laboratory Accreditation Cooperation (ILAC), the Asia Pacific Laboratory Accreditation Cooperation (APLAC), and the European Cooperation for Accreditation of Laboratories (EAL), etc.,

c. Serve as the primary U.S. signatory on behalf of NACLA members for new international laboratory accreditation agreements with foreign national, regional and coordination bodies.

d. Work toward a truly North-American system for laboratory accreditation.

6. Provide means for financial support.

NACLA should be a legally chartered public/private entity that will: agree on criteria and procedures used for accreditation and recognition of accreditation (following international guidelines) in the United States, review uniform implementation of procedures and provide a mechanism for appeal of decisions, provide for governmental (or appropriate industry) recognition of accreditation, and provide U.S. representation to international fora; and provide recognition of U.S. accreditations for foreign governments. Accreditation is performed by accrediting bodies (private and public sector); "official" recognition is provided by governmental bodies. When a number of accrediting bodies are recognized as competent, a user will be able to select among them. Reciprocity among accreditors will be based on a common recognition by NACLA authorities, which can include peer assessment of accreditors if acceptable by the authority requiring accreditation (private sector or regulatory agency). Peer evaluation may take the form of mixed private sector/public sector teams.

\section{NACLA Structure}

\section{Vision}

The NACLA vision is one of a U.S. laboratory accreditation system that includes a cooperative relationship among the public and private sectors and achieves the following:

For the testing laboratory, a single accreditation in a given field of testing, with worldwide recognition of the laboratory's competence.

For the user, a test performed once, with worldwide acceptance.

Accreditation based on uniform criteria is intended to ensure that a laboratory is qualified to provide data of consistent quality.

Guiding Principles (these principles were developed for presentation at the Forum, but have been modified slightly to serve as principles for the NACLA structure).

- Realize the Vision: universal acceptability of the results of any valid test or calibration performed by a competent laboratory accredited by a NACLA recognized accreditor.

- Eliminate duplication and inefficiency in the current laboratory accreditation process and enhance U.S. competitiveness in domestic and global markets. 
- Develop a comprehensive and rigorous domestic system, using appropriate domestic and international guides and standards, for recognizing competent laboratories, both governmental and private sector, to promote acceptance of their results by domestic and foreign regulators and product purchasers.

- Exercise appropriate government oversight at Federal, state, and local levels to ensure satisfaction of regulatory requirements (does NOT imply setting of regulatory requirements).

Achieve recognition by the U.S. government when such recognition is necessary for a laboratory's accreditation to be accepted by foreign governments.

- Allow for participation by all parties to laboratory accreditation, including consumers, laboratory customers, testing laboratories, accrediting bodies, and organizations (both public and private sector) that require accreditation in the United States.

0

Apply appropriate domestic and international guides and standards for accreditation and recognition, and adapt them to meet the special requirements of Federal and state regulatory bodies or particular user's needs (some agencies may need to specify sector requirements for specific regulatory requirements and purposes).

0

Ensure that all laboratories (i.e., manufacturer's, third-party independent, and government) are equally eligible to apply for accreditation, and that equivalently rigorous procedures are used to accredit each laboratory in a given field (some regulatory agencies may limit acceptance of accreditation for mandated programs to third-party or independent laboratories).

0

Ensure formulation of and adherence to appropriate ethical principles and standards of conduct in all NACLA operations.

\section{Mission}

To develop and administer common accreditation procedures that can be accepted by all NACLA parties to provide coordination and focus for laboratory accreditation programs in the U.S. and to serve national and international needs in laboratory accreditation.

\section{Objective}

To bring together the various parties who require accreditation, who perform accreditation, and who are accredited, to develop and administer common accreditation procedures that can be reciprocally accepted (regardless of accreditor) by different authorities requiring accreditation. The active participation by government agencies will allow them to ensure that regulatory needs are met without multiple or duplicate accreditations of laboratories, while the active participation by both accreditors and laboratories will allow their input into the development and implementation of technically sound, realistic procedures for accreditation. 


\section{Composition}

NACLA is a partnership of public and private organizations with an interest in laboratory accreditation: they include government agencies (Federal, state and local), industrial firms and associations, standards organizations, accreditors, laboratories and laboratory associations, and other interested parties.

\section{Authority and Responsibility}

NACLA is empowered on behalf of its participating organizations to act in their behalf, and is to be, both nationally and internationally, the U.S. entity to coordinate laboratory accreditation activities, and develop and represent U.S. positions for regional and international organizations dealing with laboratory accreditation with authority in the area of laboratory accreditation. It is hoped that government agencies will participate in and rely on NACLA recommendations in carrying out their regulatory and other governmental responsibilities.

\section{Organizational Structure}

Membership - Membership is open to all interested parties who subscribe to the NACLA vision, principles and protocols through a formal application process. Upon application, an organization will state its stakeholder interest.

Board of Directors - The Board is the policy making and governing body of NACLA. It includes a balanced representation from laboratories, assessors, users and other Stakeholder Committees. Representatives may be either public or private sector. ANSI serves, ex officio, as a member of the Board. Board members are elected by their respective group and serve for staggered 3-year terms. The Board maintains liaison with other national and international accreditation and recognition bodies. The Board also serves as the NACLA appeals body.

Operations Committee - The Operations Committee, the technical arm of NACLA, is responsible for granting recognition to accreditors, dealing with standards and assessment issues, operational procedures and other technical matters. It too has broad representation from a balance of affected interests. It is appointed for a fixed term by the Board based on nominations of the Stakeholder Committees.

Stakeholder Committees - Each substantial interest, or stakeholder, will have its own Committee, where its perspectives and specific issues can be discussed and resolved. The Committees will nominate Board representatives and representatives to the Operations Committee. Each new committee must be approved by the Board. Committees envisioned include ("Government" includes all Federal, state and local levels):

Government Regulators, Non-regulatory Officials, Accreditors, Manufacturers and Industries, Trade Associations, Independent and Allied Laboratories, Code Authorities, Professional and Standards Bodies, Council of Consumers and Other Interested Parties. 
Any entity that performs more than one function may be represented in more than one committee. Committees are responsible for surfacing issues related to their own constituencies and proposing solutions for decision by the Board.

Secretariat - The Secretariat is responsible for implementing Board Decisions and coordinating Operations Committee activities. The Board will decide at an appropriate time as to who will provide the Secretariat.

\section{NACLA Operational Functions}

Accreditation Standards - Relevant national and international standards, such as ISO/IEC Guide 58 for Accreditors, ISO/IEC Guide 43 for Proficiency Testing, and ISO/IEC Guide 25 for Laboratories, should form the basis for procedures used by NACLA participants. In consultation with the Stakeholder Committees, additional procedures must be approved by the Board of Directors.

Assessment of Accreditors - The Operations Committee will coordinate the audits and reviews of accrediting bodies (accreditors). It will develop detailed operating procedures in consultation with the Committee of Accreditors for approval by the Board. (NOTE: One possible assessment model that might be considered is a peer review process, such as that used in EAL and in APLAC. If used in NACLA, the review team for assessment of a private-sector accrediting body might have a majority of private sector accreditors; a review team for a government accreditor would have a majority of accreditors from the government sector. Another possible model is for recognition using appropriate ISO/IEC guides by the authority having jurisdiction, again using appropriate NACLA procedures).

Recognition of Accreditors - Decisions of the Operations Committee will be final, but may be appealed to the Board for final decision.

Listing of Recognized Accreditors and Laboratories - The NACLA Secretariat will maintain a listing of recognized accreditors and access to their lists of accredited laboratories.

Appeals Process - A full-scale appeals procedure will be developed by the Operations Committee and submitted for approval by the Board. If an accreditor applies for recognition by NACLA, but is denied that recognition, it has the right of appeal to the Board of Directors.

NACLA Interface with Regulators and Other Government Bodies - NACLA will actively work to achieve the goal of Federal agency acceptance of NACLA procedures and functions. As applicable, participating Federal agencies are encouraged to work toward harmonization of their accrediting and recognition requirements and practices with those of other public and private sector entities to the extent that the uniqueness of their underlying regulatory and public health laws allow. While special procedures may be needed and developed for a particular sector, these should be applied consistently throughout that sector. NIST will work with the Office of Management and Budget on guidance for Federal agency participation in NACLA to meet its responsibilities under the National Technology Transfer and Advancement Act of 1995 (PL 104-113) to minimize duplication and overlap in conformity assessment activities in the United States. 
NACLA Membership Obligations - All NACLA Members shall sign an agreement of mutual commitment to abide by NACLA procedures.

NACLA Interface with the International Community - NACLA will coordinate and advocate U.S. positions that are advanced in international accreditation organizations such as ILAC and APLAC.

\section{LAWG Background on NACLA}

The sponsors, along with other representatives and users of laboratory accreditation, undertook preliminary planning of NACLA based upon evaluation of key issues concerning laboratory accreditation. The LAWG Steering Group drafted the "Proposed Structure for the National Council for Laboratory Accreditation," which provides for establishing and implementing NACLA. It provides for uniform procedures for adoption and recognition of laboratory competency in testing and calibration. The planned national laboratory infrastructure includes concepts for organizational structure and operational functions that will provide for national and international recognition. The plan addresses the widely recognized need that unnecessary burdens of laboratory accreditation must be eliminated by a streamlined system that removes current duplication and unnecessary costs in laboratory accreditation.

A public forum was held in October 1995 and reported in NIST Special Publication 902, "Proceedings of the Open Forum on Laboratory Accreditation at the National Institute of Standards and Technology, October 13, 1995." Recognition of the need for a unified national system was found to be essential to satisfy domestic economic requirements and to facilitate trade. It was agreed that any infrastructure, to be successful, must be acceptable to all affected parties with recognition for the results accepted nationally, and even globally.

The establishment of NACLA requires that organizational descriptions are complete and appropriate to the intended purposes and functions, operational procedures and processes. Expansion of details are necessary as well as further refinement of composition of the Board of Directors, Stakeholder(s) Committees and their scope, Secretariat, membership, and other issues leading to "one-stop-shopping" in testing and laboratory accreditation.

The essential concept was put forth in the challenges raised by the National Research Council study of Standards, Conformity, Assessment and Trade, "......domestic policies and procedures for assessing conformity of products and processes to standards require urgent improvement." In the National Technology Transfer and Advancement Act of 1995 (P.L. 104-113), NIST was charged with coordinating Federal, state and local conformity assessment activities with those of the private sector to eliminate unnecessary duplication and complexity. The planned NACLA activities are in response to this challenge.

The discussion of issues at the forum is intended to achieve consensus on the planning document so that an organization which reflects national priorities and needs can be established. Efficient accreditation procedures with provision for reciprocity in mutual recognition of laboratory competence reflect a national priority for "one-stop-shopping" laboratory accreditation. 

APPENDIX B

Presentations 



\section{JANUARY 7, 1997}
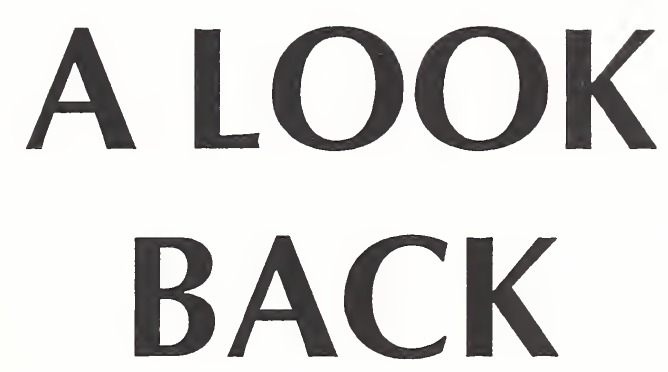

AT LAWG

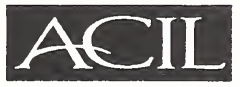

$B-3$ 
MEETING OF

ACIL, ANSI AND NIST AT NIST

HEADQUARTERS 
LAWG Retrospective

8/22/94

\section{FIRST OPEN \\ MEETING \\ AT NIST}


Fall, 94

FIRST

TASK GROUP

MEETINGS 


\section{LAWG Retrospective}

\section{$12 / 12 / 94$}

2ND OPEN

MEETING

AT U.S. CHAMBER 


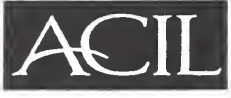

LAWG Retrospective

Jan. 95

FIRST MEETING OF LAWG

STEERING COMMITTEE 


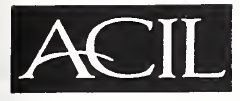

LAWG Retrospective

STEERING COMMITTEE

MEMBERS:

- NIST, EPA, FDA, MSHA

- ACIL, ANSI

- A2LA, AIHA, ICBO

- FORD, H-P 
$2 / 22 / 95$

NRC STUDY

RELEASED: PROBLEM

HIGHLIGHTED 
LAWG Retrospective

Summer, 95

\section{VISION AND \\ PRINCIPLES \\ IDENTIFIED}


OPEN FORUM ON LAB

ACCREDITATION AT NIST 
March, 96

\section{TECH TRANSFER BILL SIGNED}

INTO LAW: NEW ROLE FOR NIST 
April, 96

NACLA PROPOSED

TO LAWG

STEERING

COMMITTEE 
Sept., 96

NACLA CONCEPT

SUPPORTED

AT ILAC

IN AMSTERDAM 
Oct., 96

JAN. 7 FORUM

ON NACLA

ANNOUNCED 
$\underline{\text { Nov., } 96}$

\author{
DRAFT PLAN \\ FOR NACLA \\ IMPLEMENTATION \\ APPROVED
}




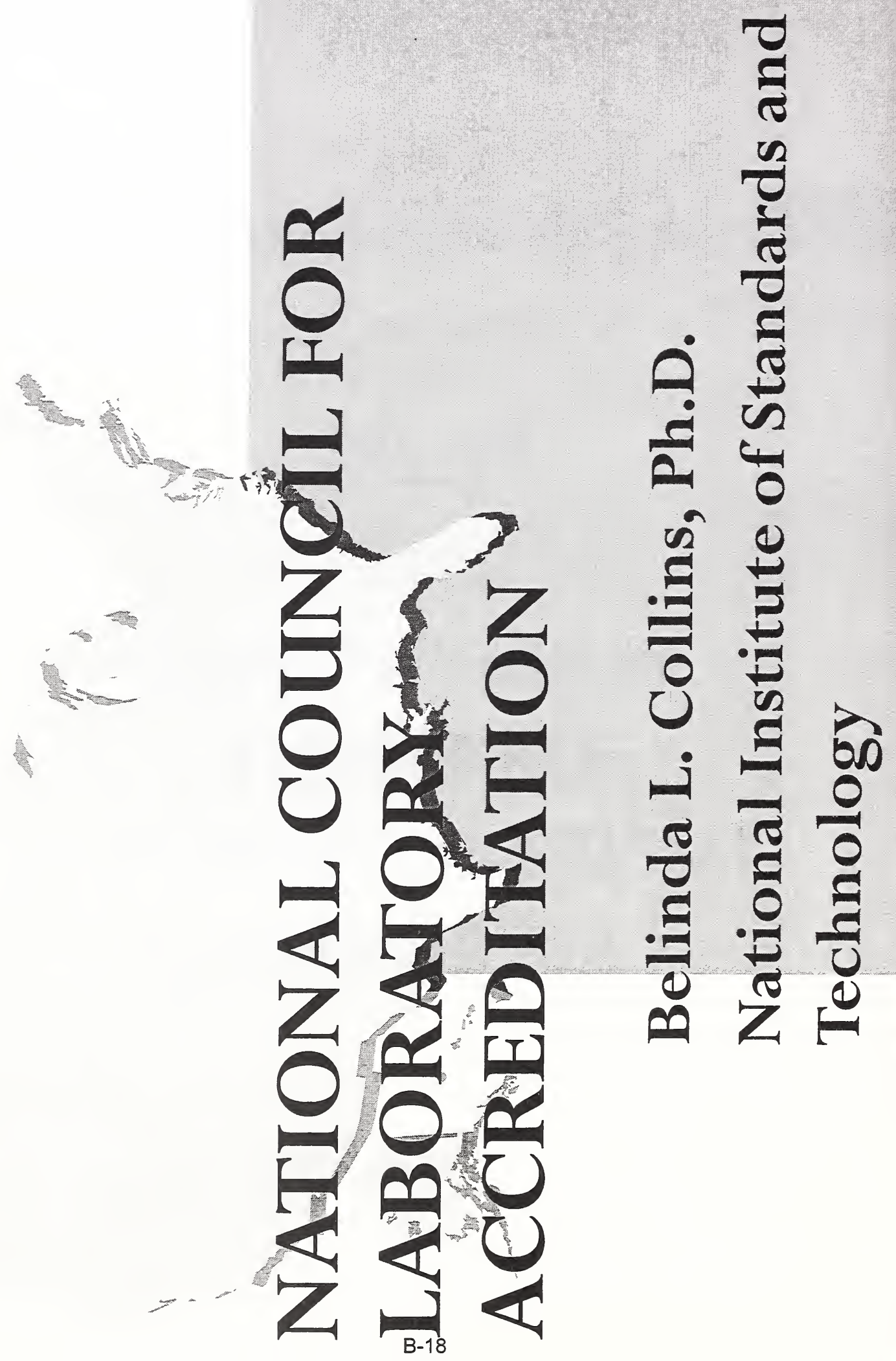





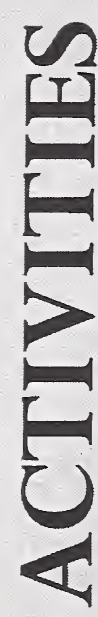

$\frac{2}{2}$

$-1, \sqrt{3}$

$-$

;
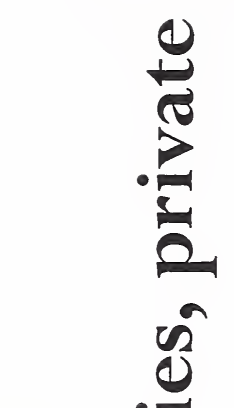

(1)

bo

ㄹ

(1) bo

잉 톨

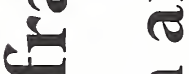

ஏ है

]

루

U

-

ช 8

की

อ 늘

ชี

$\because$

담

כี

$\frac{\text { v }}{2}$

ช

0

0

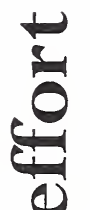

m

$F$

$\sum_{0}^{1} \frac{0}{0}$

a 60

들

$\varangle$. 크

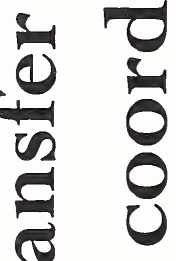

늠

$1 F$

6o us

$\frac{0}{0} \mathrm{Z}$

르

ช

$\because 2$ 




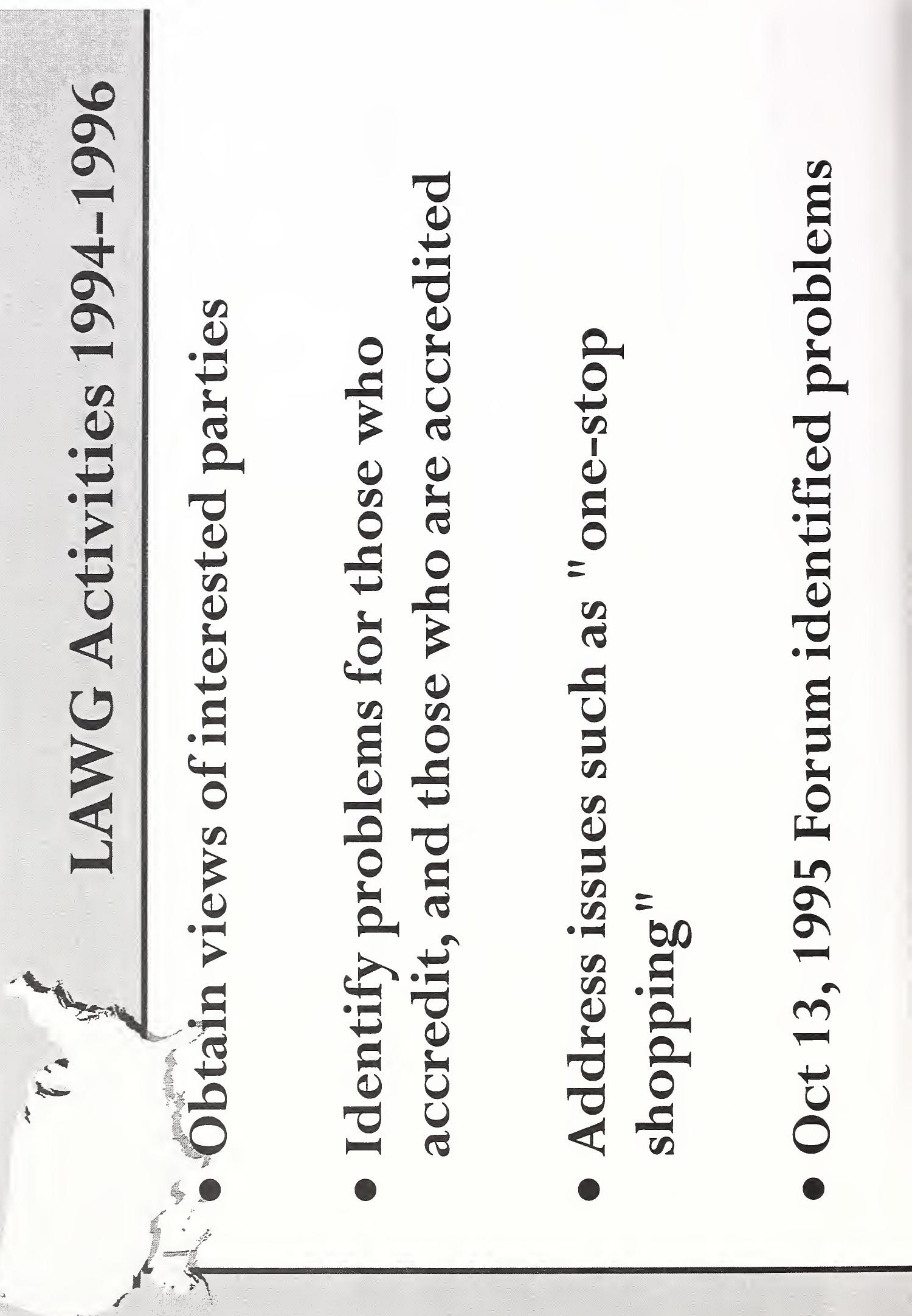





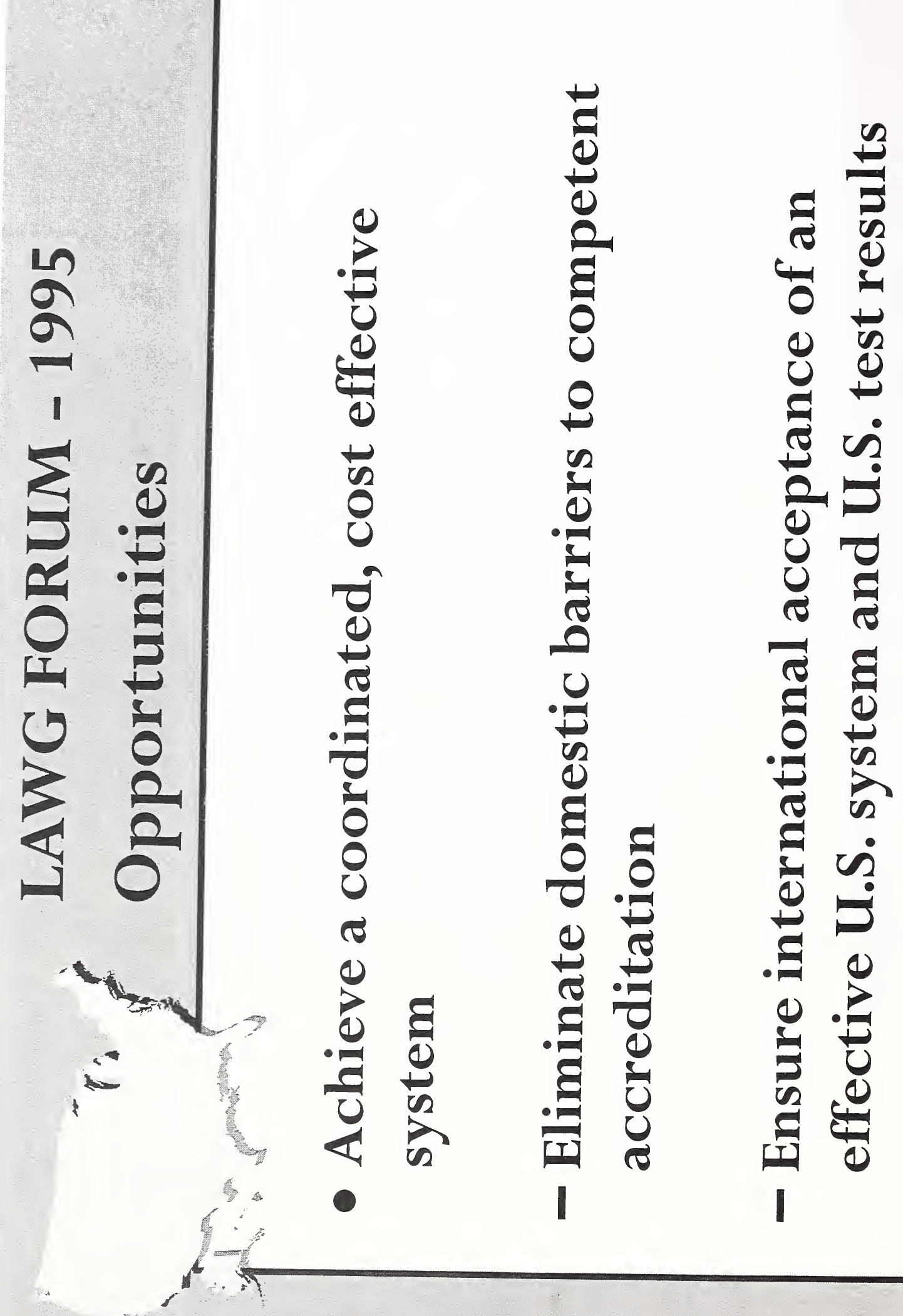




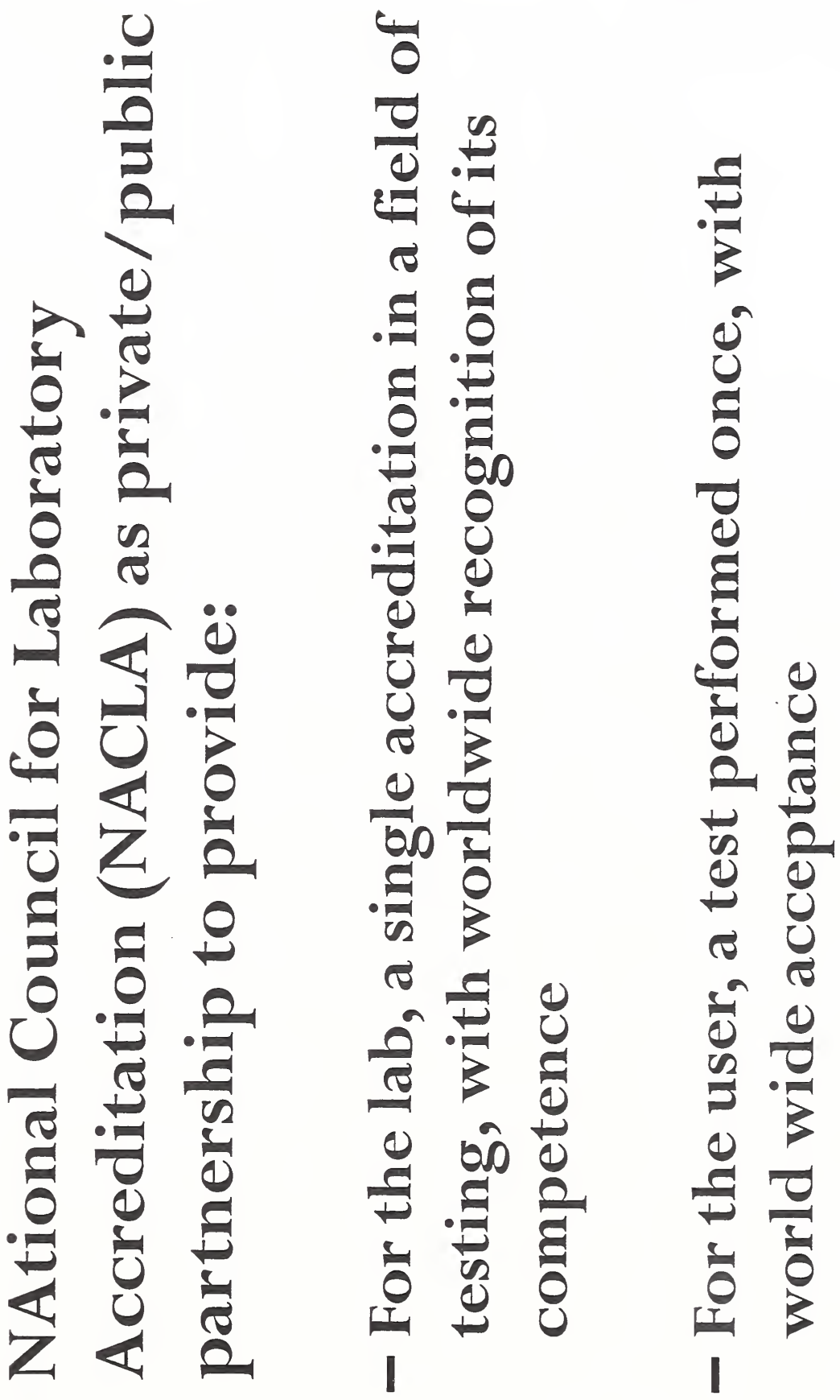




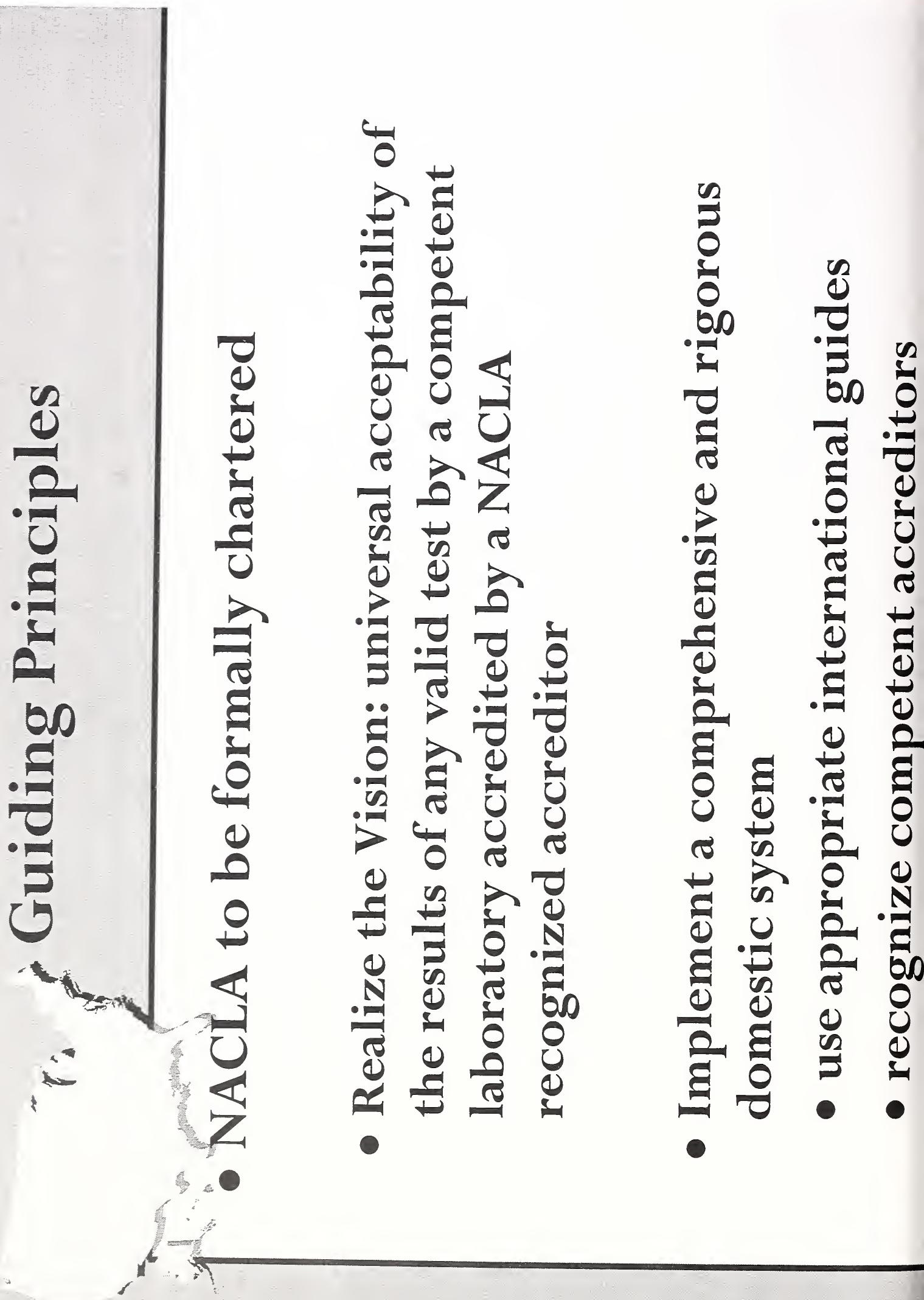




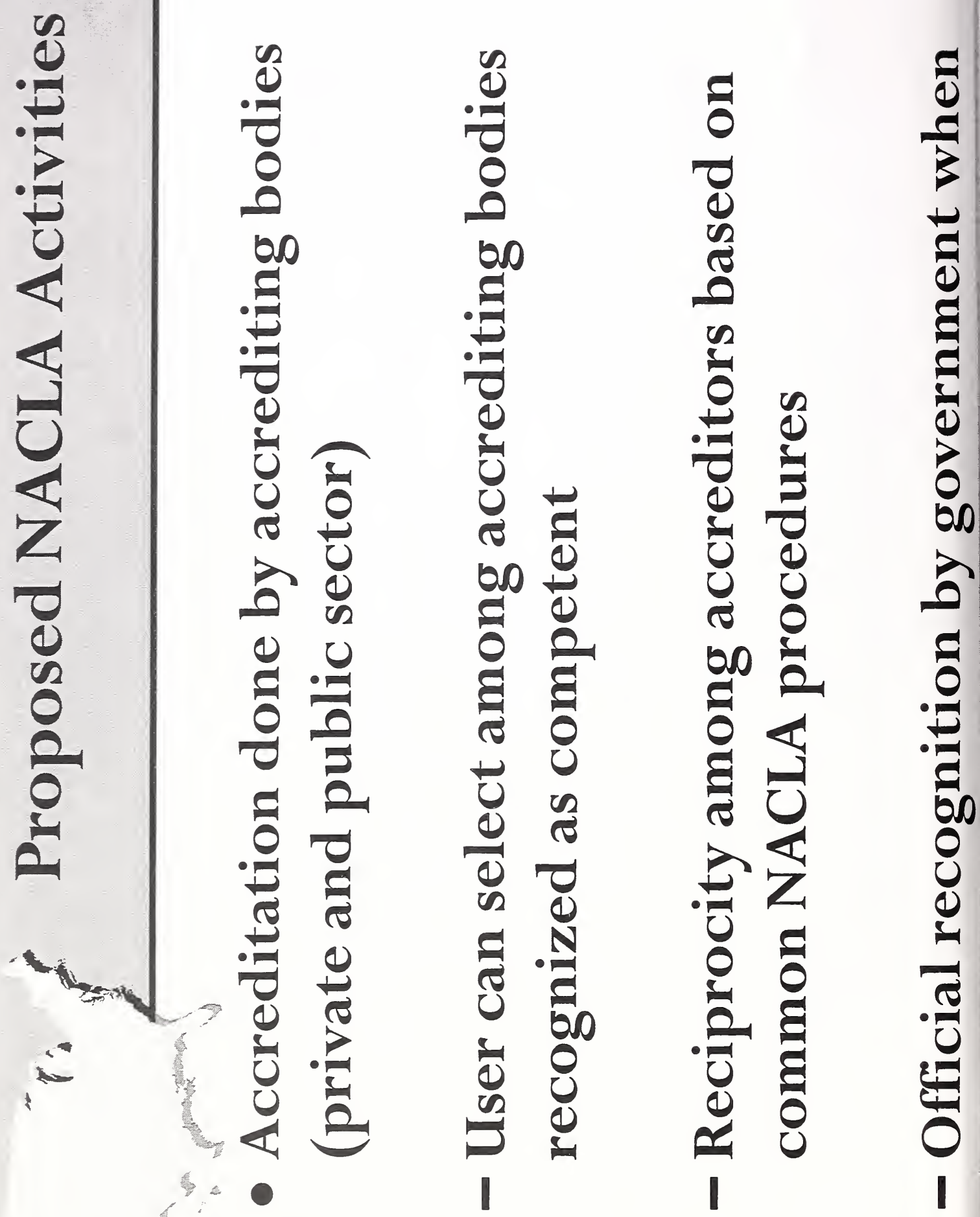



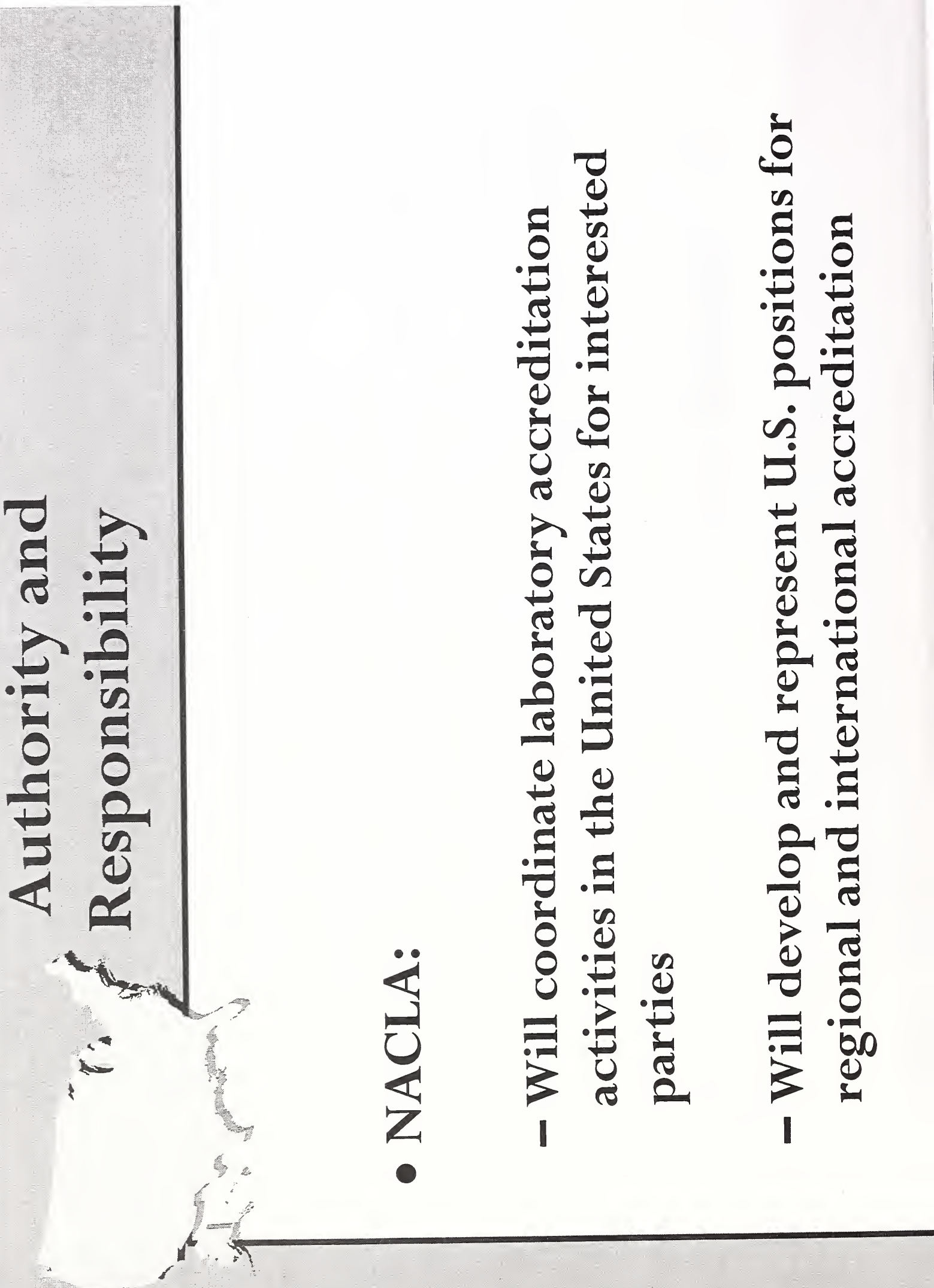



SINCE THE FORUM, THE FOLLOWING ACTIONS HAVE OCCURRED. 


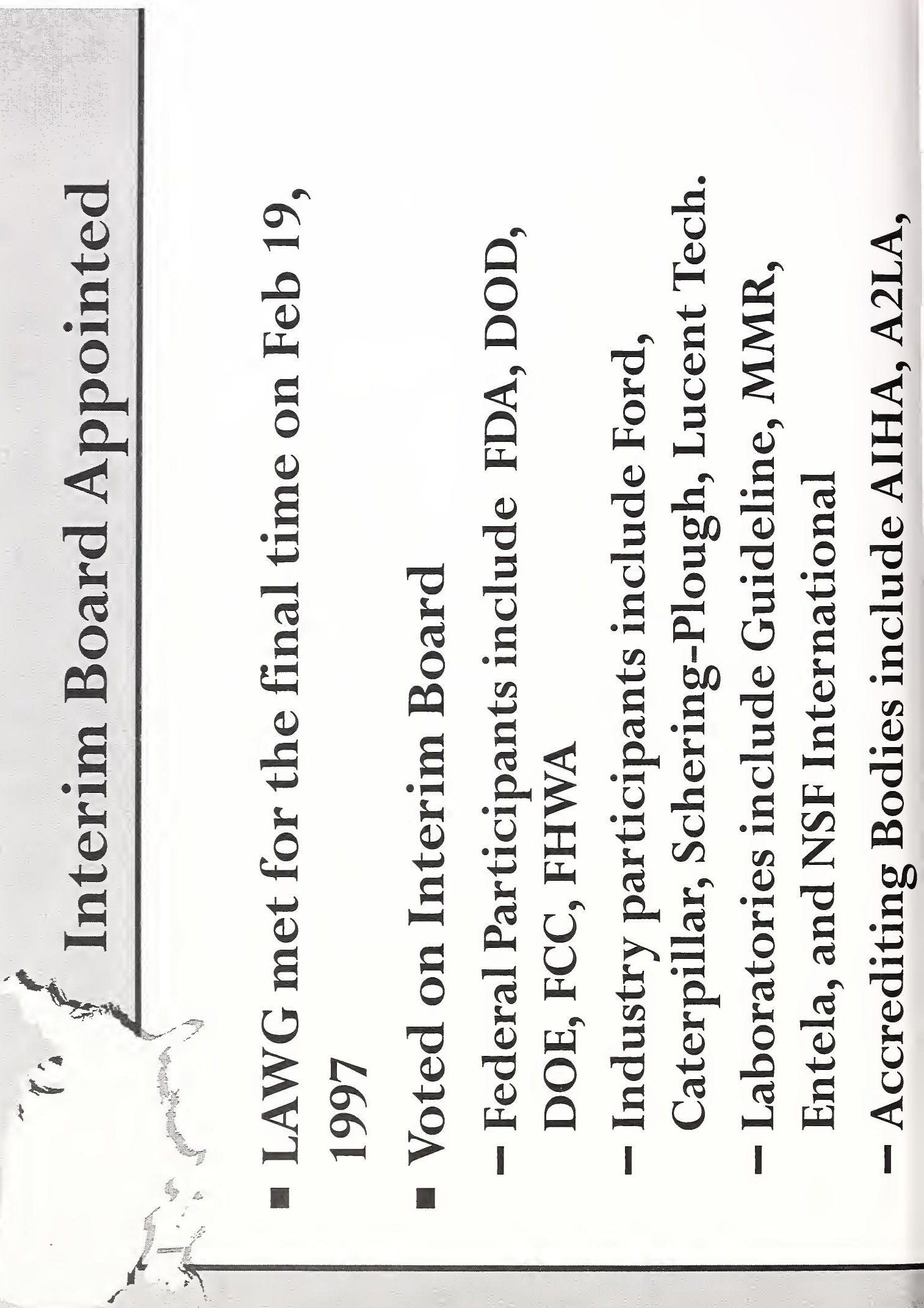





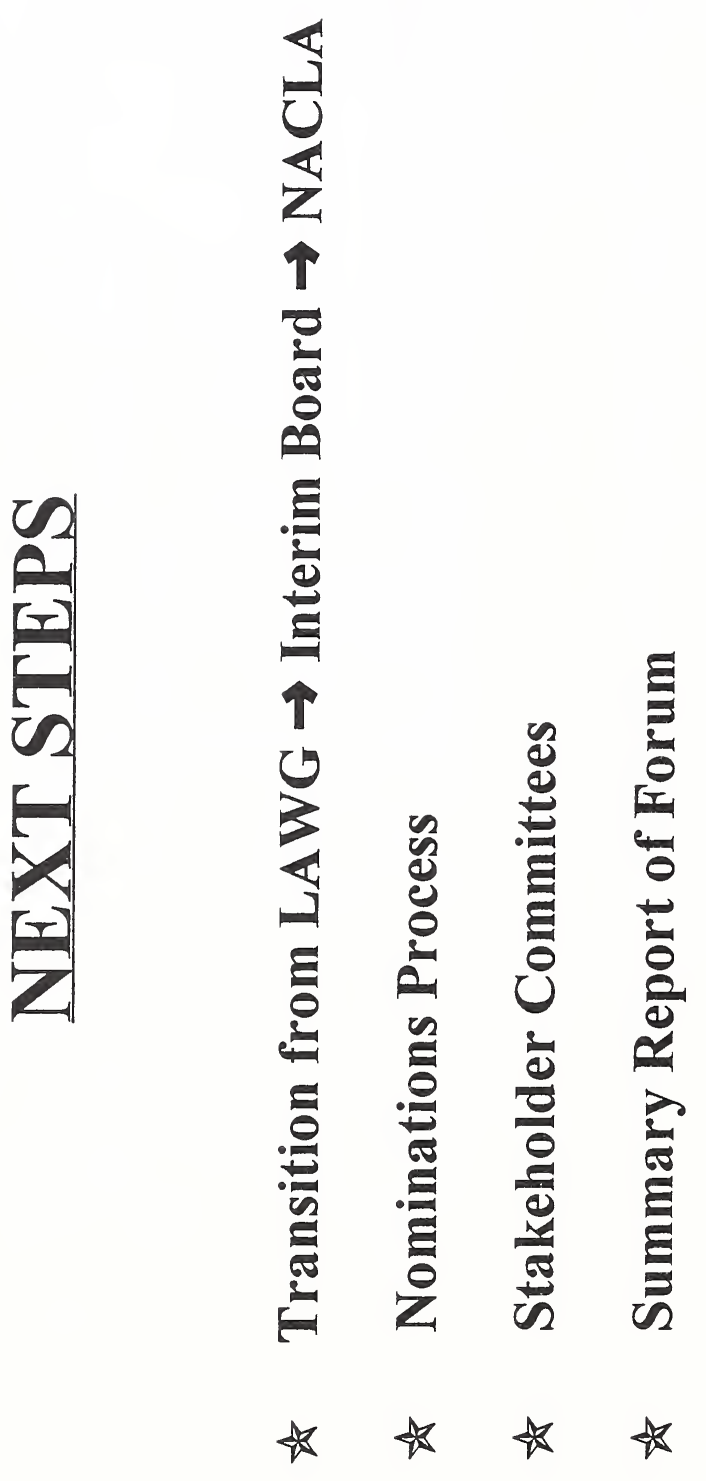




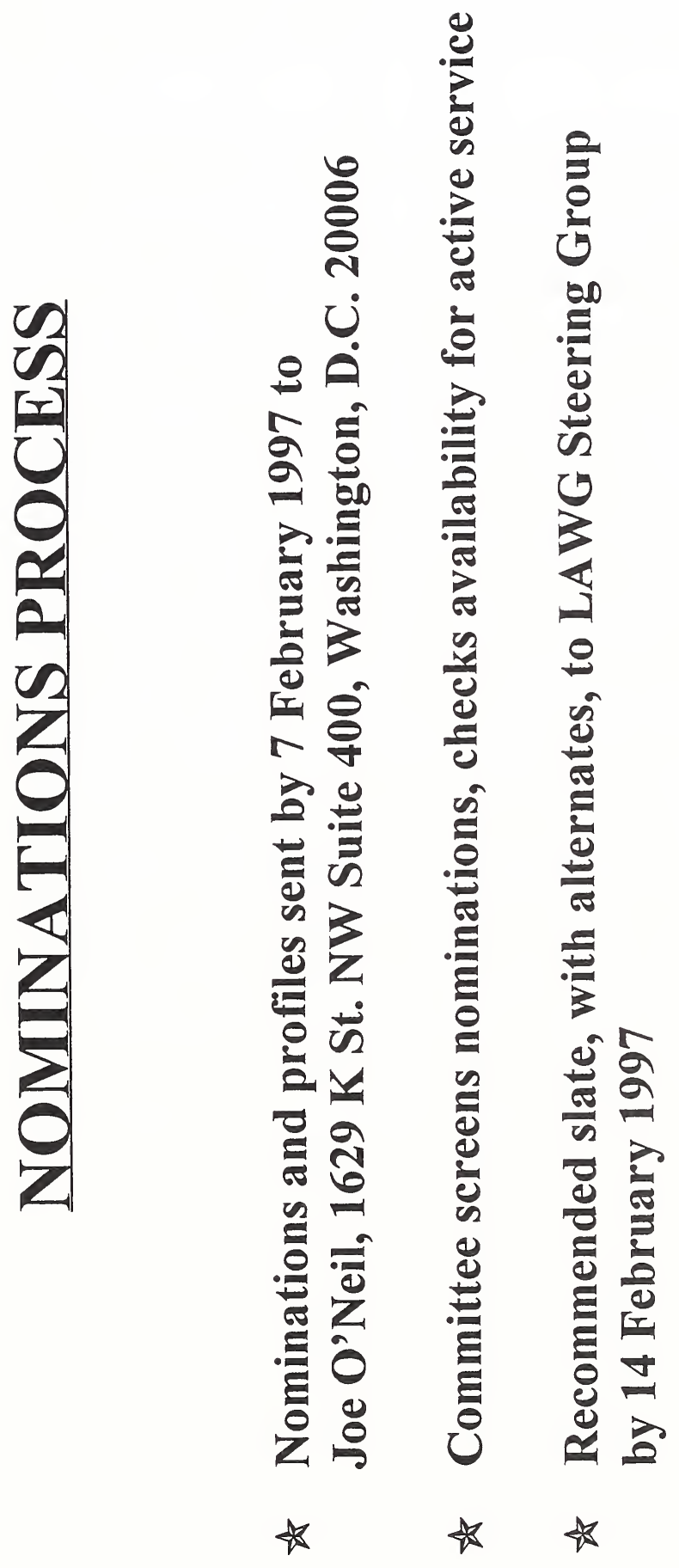




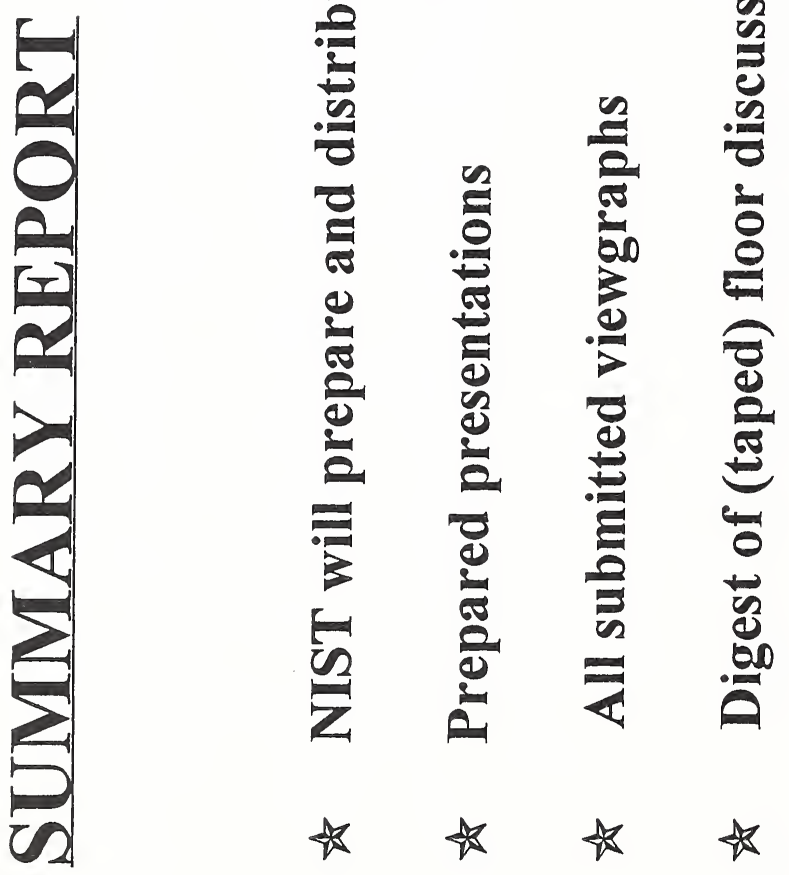




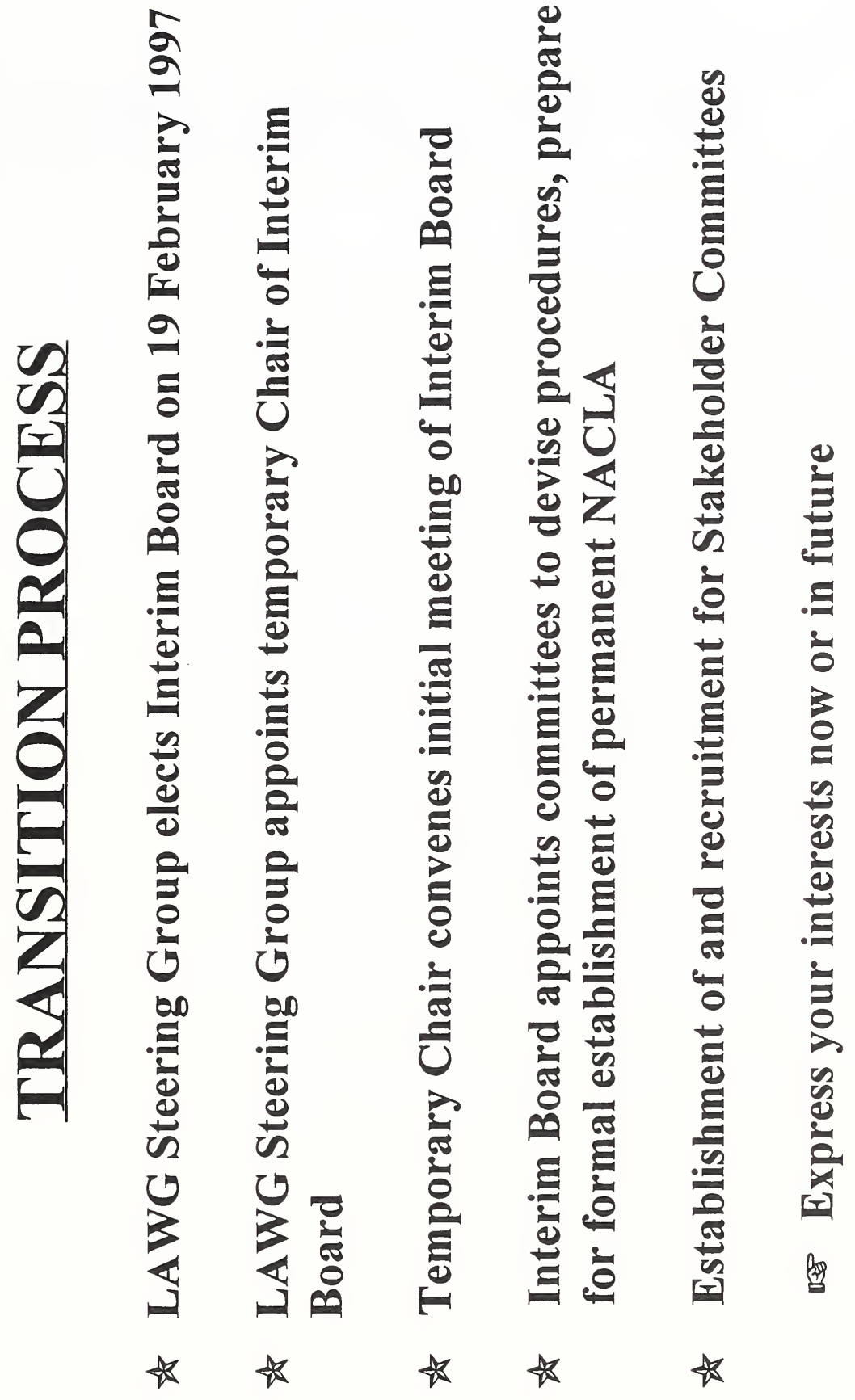


ACIL LAWG Nominating Committee

\section{CharGE:}

\section{TO NOMINATE AN INTERIM}

BOARD OF DIRECTORS FOR NACLA 
ACIL LAWG Nominating Committee

\section{COMPOSITION:}

$$
\begin{aligned}
& \text { - J. O'Neil, ACIL } \\
& \text { - W. LeIGHt, NIST } \\
& \text { - J. LoCKe, A2LA }
\end{aligned}
$$




\section{ACIL Interim NACLA Board}

\section{ROLE:}

\section{TO GET NACLA}


ACII Interim NACLA Board

TERM:

ONE YEAR 


\section{ACIL Interim NACLA Board}

\section{SIZE - 18:}

- 4 from labS

- 4 FROM INDUSTRY

- 4 fROM GOVERNMENT

- 3 FROM ACCREDITORS

- 2 fROM GENERAL INTEREST

- Chair, NIST OSS Dir. 


\section{ACII Interim NACLA}

Board

\section{SCHEDULE:}

- 1/7- Nominations

OPENED

- 2/7- Nominations

CLOSED

- 2/19- BoARD SLATE APPROVED 


\section{ACIL Interim NACLA Board}

\section{CRITERIA FOR NOMINEES:}

- INTEREST

- KNOWLedGe

- Commitment to Meetings

- Willingness to Work 


\section{ACIL Interim NACLA}

Board

\section{How to Nominate:}

Complete Nomination Form

- Hand in todar

- Mall to ACIL 1629 K ST., N.W.

WASHINGTON, D.C. 20006

- Fax to ACIL

202-887-0021 



\section{Final Participants List}

\section{Open Forum on the Establishment of NACLA}

January 7, 1997

\section{National Institute of Standards and Technology Gaithersburg, Maryland}

Deidra Abbott

College of Amer. Pathologists

1350 I St., NW

Ste. 590

Washington, DC 20005 USA

Telephone: 202/371-6617

Fax: 202/371-0028

Email: dabbott@cap.org

A. Edward Abney

U.S. Army TMDE Activity

AMSMI-TMDE-SR-D

Bldg. 5417

Redstone Arsenal, AL 35898-5400

USA

Telephone: 205/876-1786

Fax:205/876-3816

Richard Alberg

Maxim Technologies, Inc.

662 Cromwell Ave.

St. Paul, MN 55114 USA

Telephone: 612/659-7528

Fax: 612/659-7229

David Aldermann

NIST

Bldg. 820, Rm. 282

Gaithersburg, MD 20899-0001

USA

Telephone: 301/975-4019
James Allgire

Food \& Drug Admin.

1114 Market St.

Rm. 1002

St. Louis, MO 63101 USA

Telephone: 314/539-2011

Fax: 314/539-2113

Nick Almasy

Michigan Dept. of Ag.

P.O. Box 30017

Lansing, Ml 48909 USA

Roger Amorosi

Detroit Testing Lab, Inc.

1202 Lakeview Pkwy.

HC73, Box 854A

Locust Grove, VA 22508 USA

Telephone: 540/972-4126

Fax: 540/972-4126

Frederick Anderson

Analytical Standards, Inc.

6331 Emerson Ave.

Parkersburg, WV 26101 USA

Telephone: 304/422-4274

Fax: 304/422-4761
Jay Anderson

Mattson Instruments

5337 Duke Ct.

Frederick, MD 21703 USA

Telephone: 301/695-6981

Fax: 301/695-1114

Email: j.anderson@mattsonir.com

Pierre Angers

Hydro-Quebec

600 , Ave De La Montan

Shawinigan, Quebec, CANADA

Telephone: 819/539-1427

Fax: 819/539-1409

Email: angers@|tee.hydro.qc.co

Susan Arsenault

Tensile Testing

7815 Harvard Ave.

Cleveland, OH 44105 USA

Telephone: 216/641-3290

Fax:216/641-1223

Francis Azzarto

General Electric Aircraft Eng. 1000 Western Ave.

M/D 16802

Lynn, MA 01910 USA

Telephone: 617/594-8263

Fax: 617/594-1528

Email: francix.azzart@ae.ge.com 
David Baker

U.S. Air Force

813 Irving Wick Dr., W

Ste. 4M/AFMETCAL

Heath, $\mathrm{OH}$ 43056-6116 USA

Telephone: 614/788-5001

Fax: 614/788-5021

Steve Balcerzak

U.S. Navy/IVWAD

1875 W. Mission Blvd.

P.O. Box 2426

Pomona, CA 91769-2426 USA

Telephone: 909/620-0436

Fax: 909/620-0586

Richard Baldwin

Food \& Drug Admin.

5600 Fishers Lane

Rm. 12-41, HFC 140

Rockville, MD 20857 USA

Telephone: 301/443-6388

Fax: 301/443-6388

Jim Ballantine

Rice Lake Weighing Systems

1501 Kern Ave.

Rice Lake, WI 54868 USA

Telephone: 715/234-9171

Fax: 715/234-6967

Frank Bandy

Unified Industries, Inc.

6551 Loisdale Ct.

Ste. 400

Springfield, VA 22150 USA

Telephone: 703/922-9800
Jewel Barlow

GLM Wind Tunnel

Univ. of MD

Bldg. 081

College Park, MD 20742 USA

Telephone: 301/405-6871

Fax: 301/314-9628

Ron Baumgardner

Rollin, Inc.

P.O. Box 308

Stroudsburg, PA 18360 USA

Telephone: 717/424-2632

Fax: 717/424-2783

Greg Bayens

Naval Sea Systems Command

2531 Jefferson Davis Hwy.

Arlington, VA 22242 USA

Telephone: 703/602-2224

Michael Black

Acoustic Systems

415 E. Elmo Rd.

Austin, TX 78745 USA

Telephone: 512/444-1961

Fax: 512/444-2282

Andrew Blackwood

Structure Probe, Inc.

P.O. Box 656

West Chester, PA 19381-0656

USA

Telephone: $610 / 436-5400$

Fax: 610/436-5755

Donald S. Blomquist

NIST

Bldg. 233, Rm. B108

Gaithersburg, MD 20899-0001

USA

Telephone: 301/975-6600

Fax: 301/869-3536
Ken Bower

Los Almos National Lab.

MS K484

Los Almos, NM 87545 USA

Telephone: 505/665-2578

Email: kebower@lanl.gov

David Bowman

BOCA Evaluation Services, Inc. 4051 W. Flowwmoor Rd.

Country Club Hills, IL 60478 USA

Telephone: 708/799-2305

Fax: 708/799-0310

Email: dbowman@bocai.org

Steve Bowser

Bowser-Morner, Inc.

4518 Taylorsville Rd.

P.O. Box 51

Dayton, OH 45401 USA

Telephone: 937/236-8805

Fax: 937/233-2016

Matt Bowyer

Natl. Inst. Occup. Safety \& Health 1095 Willowdale Rd.

Morgantown, WV 26505 USA

Telephone: 304/285-5991

Fax: 304/285-6030

Lynn Bradley

ASTPHLD

1211 Connecticut Ave., NW

Ste. 608

Washington, DC 20036 USA

Telephone: 202/822-5227

Fax: 202/887-5098 
Zandall Bright

EAl Corp.

308 Continental Dr.

ite. J

tbingdon, MD 21009 USA

ielephone: 410/676-1449

ax: 410/671-7241

lary Bruce

jtruers

310 Sharon Dr.

Nestlake, OH 44145 USA

relephone: 216/871-0071

ax:216/871-8188

:mail: struers@clevelandoh.com

lary Bruch

Jary Bruch Micro Reg.

:16 M. Edwards Ferry Rd. .eesburg, VA 22075 USA

relephone: 703/589-1514

ax: 703/779-0267

jarl Burrell

Javis \& Floyd, Inc.

?.O. Drawer 428

ìreenwood, SC 29648 USA

ielephone: 864/229-4413

ax: 864/229-7119

:mail: cburrell@davisfloyd.com

larc Butler

Aicro Motion, Inc.

'070 Winchester Cir.

3oulder, CO 80301 USA

-elephone: 303/530-8562

ax: 303/530-8596

:mail:marcb@micromotion.com
R. Douglas Carlson

DOE/RESL

850 Energy Dr.

MS 4149

Idaho Falls, ID 83401 USA

Telephone: 208/526-2143

Fax: 208/526-2548

Email: carlsord@inel.gov

Kumar Chaklashiya

Compatible Electronics, Inc.

114 Olinda Dr.

Brea, CA 92823 USA

Telephone: 714/579-0500

Fax: 714/579-1850

Russ Chaney

IAPMO

20001 Walnut Dr., S.

Walnut, CA 91789-2825 USA

Telephone: 909/595-8449

Fax: 909/594-1537

Email: gpchaney@iapmo.org

Peter Chen

U.S. Army/TMDE Activity

10115 Duportal Rd.

Ft. Belvoir, VA 22060 USA

Telephone: 703/704-2407

Tom Chesworth

Seven Mountains Science, Inc.

P.O. Box 650

Boalsburg, PA 16827 USA

Telephone: 814/466-6559

Fax: 814/466-2777

Email:sevmtnsci@aol.com
Ronald R. Christensen

AOAC International

481 N. Frederick Ave.

Ste. 500

Gaithersburg, MD 20877-2417

USA

Telephone: 301/924-7077

Fax: 301/924-7089

Duane Christy

Federal Products Co.

1144 Eddy St.

Providence, RI 02940 USA

Telephone: 401/784-3271

Fax: 401/784-3344

Email:dchristy@fedprod.com

Scott Coates

AOAC

481 N. Frederick Ave.

Gaithersburg, MD 20877 USA

Telephone: 301/924-7090

Fax: 301/924-7089

Email: scoates@aoac.org

Wendy Blake Coleman

U.S. EPA

401 M. Street

Washington, DC 20460 USA

Telephone: 202/260-5680

Fax: 202/260-7929 
Belinda Collins

NIST

Bldg. 820, Rm. 282

Gaithersburg, MD 20899-0001

USA

Telephone: $301 / 975-4000$

Email: bcollins@nist.gov

Patrick Cooke

NIST

Bldg. 820, Rm. 282

Gaithersburg, MD 20899-0001

USA

Telephone: 301/975-4033

Alan Cookson

NIST

Bldg. 220, Rm. B164

Gaithersburg, MD 20899-0001

USA

Telephone: 301/975-2220

Fax: 301/975-4091

Email:alan.cookson@nist.gov

Tag Coolidge

Talem, Inc.

P.O. Box 3270

Ft. Worth, TX 76113 USA

Telephone: 817/335-1186

Email: 75774.3642@

compuserve.com

Ted Coopwood

U.S. Environmental Protection Agy.

401 M St., SW

MS 6601J

Washington, DC 20460 USA

Telephone: 202/233-9358

Fax: 202/233-9651
Joseph Cotruvo

NSF International

1301 K St., NW

MC 225

Washington, DC USA

Telephone: 202/289-2140

Fax: 202/289-2149

Email:cotruvo@nsf.org

Bert Coursey

NIST

Bldg. 245, Rm. C229

Gaithersburg, MD 20899-0001

USA

Telephone: 301/975-5584

Fax: 301/869-7682

Jim Crane

Keithley Instruments, Inc.

28775 Aurora Rd.

Solon, OH 44139 USA

Telephone: 216/498-2904

Fax:216/248-6168

Jon Crickenberger

NIST

Bldg. 820, Rm. 282

Gaithersburg, MD 20899-0001

USA

Telephone: 301/975-5305

Gayle Crist

Amtek Inc., US Gauge Div.

8600 Somerset Dr.

Largo, FL 33773 USA

Telephone: 813/536-7831

Fax: 813/532-3329

Richard Cubbage

Kema Powertest

4379 County Line Rd.

Chalfont, PA 18914 USA

Telephone: 215/822-4242

Fax: 215/822-4267
Charles Cullari

Standford Technologies

57 Poplar St.

Box 2100-D

Glenbrook, CT 06906 USA

Telephone: 203/348-4080

Fax: 203/327-5225

Robert Curry

Plumbing Mfg. Inst.

1825 I St., NW

Ste. 400

Washington, DC 20006 USA

Telephone: 202/429-2038

Fax: 202/775-4191

Michael Curtis

Lockheed Martin

86 S. Cobb Dr.

Marietta, GA 30063 USA

Telephone: $770 / 494-9040$

Fax: 770/494-6557

Wayne Davis

SC Dept. of Health \& Environ. Ct

2600 Bull St.

Columbia, SC 29201 USA

Telephone: 803/935-7025

Fax: 803/935-6859

Thomas Davis

NIST

Bldg. 820, Rm. 282

Gaithersburg, MD 20899-0001

USA

Telephone: 301/975-6499 
-arry DeWard

Jniv. of Wisconsin

1300 University Ave.

im. 1530, MSC

Madison, WI 53706 USA

Telephone: 608/262-6320

=ax: 608/262-5012

Email: ladewerd@facstaff.wise.edu

Sharrill Dittmann

NIST

3ldg. 820, Rm. 232

Gaithersburg, MD 20899-0001

USA

Telephone: 301/975-2005

Fax: 301/869-3548

Email: dittmann@nist.gov

Louis Dixon

Ford Motor Company

330 Town Ctr. Drive

Ste. $700 \mathrm{C}$

Dearborn, MI 48126 USA

Telephone: 313/337-3800

Fax: $313 / 390-6327$

Email: Idixon@ford.com

John Donaldson

American National Standards Inst.

655 15th St.

Ste. 300

Washington, DC 20005 USA

Telephone: 202/639-4191

Fax: 202/628-1886

Roberta Dresser

Food \& Drug Admin.

5600 Fishers Lane

Rm. 15A-16, HFG-1

Rockville, MD 20857 USA

Telephone: 301/824-4480

Fax: 301/443-0235
Daniel Duggan

Natl. Standards Testing Lab

15753 Crabbs Branch Way

P.O. Box 5808

Rockville, MD 20855 USA

Telephone: 301/590-0097

Fax: 301/590-0099

Donald Dunavant

Southwest Research Inst.

6220 Culebra Rd.

MC CC 30

San Antonio, TX 78238-5166 USA

Telephone: 210/522-2942

Fax: 210/522-3693

L.F. Eason

NC Standards Lab

4040 District Dr.

Raleigh, NC 27607 USA

Telephone: 919/733-4411

Fax: 919/733-8804

Email:If_eason@

ncdamail.agr.state.nc.us

David Edgerly

NIST

Bldg. 820, Rm. 311

Gaithersburg, MD 20899-0001

USA

Telephone: 301/975-4510

Stanley Edinger

U.S. PHS/AHCPR/CIT

5901 Montrose Rd.

Ste. 14005

Rockville, MD 20852 USA

Telephone: 301/594-1486

Fax: 301/594-2333
Charles Ehrlich

NIST

Bldg. 820, Rm. 282

Gaithersburg, MD 20899-0001

USA

Telephone: 301/975-4834

Linda English

Food \& Drug Admin.

5600 Fishers Lane

Rm. 12-41, HFC-141

Rockville, MD 20857 USA

Telephone: 301/443-3320

Fax: 301/443-6388

Don Fairman

Radco

3220 E. 59th St.

Long Beach, CA 90805 USA

Telephone: 703/532-1734

C. Douglas Faison

NIST

Bldg. 820, Rm. 282

Gaithersburg, MD 20899-0001

USA

Telephone: 301/975-5304

Dave Farrant

PDE Labs

950 Calle Negocio

San Clemente, CA 92673-6201

USA

Telephone: 714/361-9189

Fax: 714/361-9597

Alim Fatah

NIST

Bldg. 225, Rm. A323

Gaithersburg, MD 20899-0001

USA 
Medhat Fawzy

Northern Telecom Ltd.

250 Sidney St.

Dept. 9845

Belleville, Ontario, K8N 5B7

CANADA

Telephone: 613/967-5520

Fax: 613/967-5364

Charles Feltes

Powers Process Controls

3400 Oakton St.

Skokie, IL 60076 USA

Telephone: 847/568-6700

Fax: 847/673-9044

Mary Anne Fennell

PA Equine Toxicology \& Res. Lab

Box 551

West Chester, PA 19380 USA

Telephone: 610/436-3501

Fax: 610/436-3504

Fred Ferate

U.S. DOT/RSPA

P.O. Box 23466

Washington, DC 20026 USA

Telephone: 202/366-4498

Fax: 202/366-3753

Email: fred.ferate@rspa.dot.gov

Fred Fetterolf

Ramball Testlab, Inc.

1703 Industrial Hwy

Unit 3

Cinnaminson, NJ 08077 USA

Telephone: 609/786-8880

Fax: 609/786-3144
Brian Fitzpatrick

Hi-Tech, Inc.

8223 Cloverleaf Dr.

Ste. 126A

Millersville, MD 21108 USA

Telephone: 410/987-4000

Fax: 410/987-4034

Dan Fliller

Sartorius, Corp.

131 Heartland Blvd.

Edgewood, NY 11717 USA

Telephone: 516/254-4249

Fax: 516/254-4252

James Floyd

Sartorius, Corp.

131 Heartland Blvd.

Edgewood, NY 11717 USA

Telephone: 516/254-4249

Fax: 516/254-4252

Judith Foeldesh

JSF Lab Certification

29673 Pine Ridge Cr.

Farmington Hills, MI 48331 USA

Telephone: 810/788-9594

Fax: 810/542-2426

Email: foldesh@aol.com

Howard Forman

Consultant

1033 Corn Crib Drive

P.O. Box 66

Huntingdon Valley, PA 19006 USA

Telephone: 215/947-4154

Fax:215/947-5036

Agatha Francis

Dept. of Veterans Affairs

810 Vermont Ave.

Washington, DC 20420 USA

Telephone: 202/273-8420

Fax: 202/273-9064
Richard Franconeri

SGS U.S. Testing Co.

291 Fairfield Ave.

Fairfield, NJ 07006 USA

Telephone: 201/575-5252

Fax: 201/575-8271

David Freemore

Detecon, Inc., TAD

1775 Old Hwy 8

Ste. 107

St Paul, MN 55112 USA

Telephone: 612/639-0775

Fax: 612/639-0873

David Friedman

U.S. EPA

$401 \mathrm{M} \mathrm{St.}$ SW

Washington, DC 20460 USA

Telephone: 202/260-3535

Email: friedman.david@

epamail.epa.gov

Leonard Frier

Met Laboratories, Inc.

914 W. Patapsco Ave.

Baltimore, MD 21230 USA

Telephone: 410/354-3300

Fax: 410/354-3313

William Furman

Food \& Drug Admin.

1114 Market St.

Rm. 1002

St. Louis, MO 63101 USA

Telephone: 314/539-2136

Fax: 314/539-2113

Paul Gaines

IV Labs, Inc.

195 Lehigh Ave.

Ste. 4

Lakewood, NJ 08701 USA

Telephone: 908/901-1900 
Lawrence Galowin NIST

Bldg. 820, Rm. 282

Gaithersburg, MD 20899-0001

USA

Telephone: 301/975-4022

Email:Igalowin@nist.gov

Chester Gaynes

Gaynes Professional Services

$420 \mathrm{E}$. Ohio St.

Ste. $9 F$

Chicago, IL 60611 USA

Telephone: 312/280-8150

Doug Geralde

Canadian Standards Assoc.

178 Rexdale Blvd.

Etobicoke, Ontario, M9W1R3

CANADA

Telephone: 416/747-4295

Fax: 416/747-4287

H.S. Gibson

Lockheed Martin Aero. Systems

$86 \mathrm{~S}$. Cobb Dr.

Dept. 73-05, Zone 0199

Marietta, GA 30063 USA

Telephone: 770/494-5632

Fax: 770/494-5207

Email:hgibson@

lg3vm.mar.Imco.com

Jo Ann Given

A.S.C.L.D.L.A.B.

9079 Hampton Blvd.

Ste. 110

Norfolk, VA 23505-1098 USA

Telephone: 757/444-8615

Fax: 757/445-4272

Email: jgiven@exis.net
Louis Gnecco

Tempest, Inc.

112 Elden St.

Herndon, VA 20170-4809 USA

Telephone: 703/836-7378

Fax:lou@tempest_inc.com

Manuel Gomez

American Indust. Hygiene Assoc.

2700 Prosperity Ave.

Ste. 250

Fairfax, VA 22031 USA

Telephone: $703 / 849-8888$

Fax: 703/207-3561

Email:mgomez@aiha.org

Mary Good

U.S. Dept. of Commerce

Rm. 4824, HCHB

Washington, DC 20230 USA

Telephone: 202/482-1575

Fax: 202/501-2492

Roland Goodman

American Petroleum Institute

1220 L St., NW

Washington, DC 20005-4070 USA

Telephone: 202/682-8571

Fax: 202/962-4739

Email:goodmanr@api.org

Don Grachanen

Ruska Instruments

3601 Dunvale

Cal Service Ctr.

Houston, TX 77063 USA

Telephone: 713/975-0547

Email:dgrachan@ruska.com
Will Gray

Toshiba International Corp.

13131 W Littleyork Rd.

Houston, TX 77041 USA

Telephone: 713/466-0277

Fax: 713/466-8773

Email:wgray@tic.toshiba.com

Richard Groft

AMP, Inc.

2100 Paxton St.

Bldg. 018/MS 001

Harrisburg, PA 17111 USA

Telephone: 717/592-7855

Fred Grunder

American Indust. Hygiene Assoc.

2700 Prosperity Ave.

Ste. 250

Fairfax, VA 22031 USA

Telephone: 703/849-8888

Fax: 703/207-3561

Email: fgrunder@aiha.org

Kenneth Hanks

Sandia National Labs

P.O. Box 5800

MS 1367

Albuquerque, NM 87185 USA

Telephone: 505/271-7935

Fax: 505/271-7974

Email: kwhanks@sandia.gov

William Hanrahan

Info. Tech. Industry Council

1250 Eye St., NW

Washington, DC 20005 USA

Telephone: 202/626-5733

Fax: 202/638-4922

Email:bhanrahan@itic.nw.dc.us 
Ross Hansen

Retlif Testing Labs

795 Marconi Ave.

Ronkonkoma, NY 11779 USA

Telephone: 516/737-1500

Fax:516/737-1497

Email:72723.147@

compuserve.com

William Hanson

UT MD Anderson Cancer Ctr.

Radiation Physics

Box 547

Houston, TX 77030 USA

Telephone: 713/792-3226

Fax: 713/794-1364

Kari Harper

NIST

Bldg. 101, Rm. A1000

Gaithersburg, MD 20899-0001

USA

Telephone: 301/975-2660

Email:kharper@nist.gov

John Harrington

Acoustic Systems

415 E. Elmo Rd.

P.O. Box 3610

Austin, TX 78764 USA

Telephone: 512/444-1961

Email: 512/444-2282

Claudia Harris

N.A.P.H.C.C.

180 S. Washington St.

Falls Church, VA 22046 USA

Telephone: 703/237-8100

Fax: 703/237-7442
Bruce Harvey

Research Triangle Inst.

3040 Cornwallis Rd.

Bldg. 5, Rm. 222

RTP, NC 27709 USA

Telephone: 919/541-6573

Fax: 919/541-7386

Email: bwh@rti.org

Kathleen Hastings

HHS Food \& Drug Admin.

5600 Fishers Lane

Rm. 15-74

Rockville, MD 20857 USA

Telephone: 301/827-3349

Fax: 301/443-6906

H. Thompson Heaton II

FDACDRH,OST,DECS,RMB

12720 Twinbrook Pkwy.

Code HFZ-143

Rockville, MD 20857 USA

Telephone: 301/443-2536

Fax: 301/443-9101

Robert Hebner

NIST

Bldg. 101, Rm. A1134

Gaithersburg, MD 20899-0001

USA

Harvey Hecker

Pre-Cal Services, Inc.

271 Route 380, West

Apollo, PA 15613 USA

Telephone: 412/335-6966

Fax: 412/335-3825

Email: 103165.1461@

compuserve.com
Stephanie Heier

Simcom International 1150 18th St., NW

Ste. 875

Washington, DC 20036 USA

Telephone: 202/293-5313

Fax: 202/293-5310

Email:sheier@mail.wdn.com

Donald Heirman

Lucent Technologies

101 Crawfords Corner

Rm. 11C-165

Holmdel, NJ 07733-3030 USA

Telephone: 908/834-1801

Fax: 908/834-1807

Email:dnheirman@gpcl.lucent.cr

Wilson Hershey

Lancanster Laboratories

2425 New Holland Pike

P.O. Box 12425

Lancaster, PA 17605-2425 USA

Telephone: 717/656-2300

Fax: 717/656-0450

John Hettinger

Lockheed Martin

1111 Lockheed Way

P.O. Box 3504, 48-50/195B

Sunnyvale, CA 94088-3504 USA

Telephone: 408/756-2496

Fax: 408/742-0290

Peter Heydemann

NIST

Bldg. 820, Rm. 282

Gaithersburg, MD 20899-0001

USA

Telephone: $301 / 975-4500$ 
Alex Heyward

U.S. Air Force

813 Irving Wick Dr., W

Ste. 4M AFMETCAL DET1

Heath, OH 43056-6116 USA

Telephone: 614/788-5081

Fax: 614/788-5021

Kathleen Higgins

NIST

Bldg. 225, Rm. A323

Gaithersburg, MD 20899-0001

JSA

Telephone: 301/975-2757

Fax: 301/948-0978

Bill Hileman

Saturn Corporation

100 Saturn Pkwy.

.0. Box 1500, MD G16

Spring Hill, TN 37174-1500 USA

Telephone: 615/486-5348

Fax: $615 / 486-5680$

Julia Hill

The National Food Lab

363 Clark Ave.

Jublin, CA 94568 USA

relephone: $510 / 551-4209$

ax: 510/833-8795

Roger Hirt

General Electric

635 Braodway

US 18-3

t. Wayne, IN 46804 USA

Telephone: 214/439-2120

Fax: 219/439-4344
I-Pin Ho

U.S. Dept of Agriculture

MS 0272, Rm. 3517, S

P.O. Box 96456

Washington, DC 20090-6456 USA

Telephone: 202/205-6456

Email: ipin_ho@usda.gov

Robert Holcombe

JBS Auto Products

30 Emory St.

P.O. Box 2125

Greenville, SC 29602 USA

Telephone: 864/240-2624

Fax: 864/240-2655

Daniel Hoolihan

TUV Product Service

1775 Old Highway 8

New Brighton, MN 55112 USA

Telephone: 612/638-0250

Fax: 612/638-0285

Email:dhoolihan@tuvps.com

Jeffrey Horlick

NIST

Bldg. 820, Rm. 282

Gaithersburg, MD 20899-0001

USA

Telephone: 301/975-4020

Arnie Horoff

Laboratory Testing, Inc.

120 Mill St.

P.O. Box 249

Dublin, PA 18917 USA

Telephone: 215/249-9898

Fax: 215/249-9656

Email: lit@itw.com
James Hostetler

Kirkland \& Ellis

655 15th St., NW

Ste. 1200

Washington, DC 20005 USA

Telephone: 202/879-5152

Email: james_hosteltler@

kirkland.com

Susan Hoyler

Telecommunication Industry Assoc.

2500 Wilson Blvd.

Arlington, VA 22201 USA

Telephone: 703/907-7704

Fax: 703/907-7727

Email:shoyler@tia.eia.org

Robert Hughes

Fleet Technical Support Ctr.

P.O. Box 85548

Code 404

San Diego, CA 92186-5548 USA

Telephone: 619/524-3266

Fax: 619/524-2328

Connie Humphrey

Omega Point Labs

16015 Shady Falls Rd.

Elmendorf, TX 78112 USA

Telephone: 210/635-8100

Fax:210/635-8101

Geoffrey lbbott

Univ. of Kentucky Med. Cir.

800 Rose Street

Dept. of Rad. Med.

Lexington, KY 40536-0084 USA

Telephone: 606/323-1144

Fax: 606/323-1350

Email: ibbott@pop.uky.edu 
Janneth Iganacio

AALA

656 Quince Orchard Rd.

Ste. 620

Gaithersburg, MD 20878 USA

Telephone: 301/670-1377

Fax: 301/869-1495

Email: jignacio@a2la.org

David Inman

Chomerics

77 Dragon Ct.

Woburn, MA 01888 USA

Telephone: 617/939-4375

Email:chorts@aol.com

Janice Jablonski

Environmental Affairs

1302 Gibson Place

Falls Church, VA 22046 USA

Telephone: 703/532-7685

Roland Jenkins

Ohio Dept. of Ag.

8995 E. Main St.

Bldg. 3

Reynoldsburg, $\mathrm{OH} 43068$ USA

Telephone: 614/728-6230

Fax: 613/728-6322

Arturo Jessel

NAFTA Office, Embassy of Mexico

1911 Pennsylvania Ave., NW

Washington, DC 20006 USA

Telephone: 202/728-1706

Fax: 202/728-1712

Carolyn Johansen

JJ Electronics

8039 SW Circus Dr.

Beaverton, OR 97008 USA

Telephone: 503/644-1819

Fax: 503/641-3237

Email: jjelect@telport.com
Jan Johansen

JJ Electronics

8039 SW Circus Dr.

Beaverton, OR 97008 USA

Telephone: 503/644-1819

Fax: 503/641-3237

Email: jjelect@teleport.com

Ralph Johnson

Sandia National Labs

P.O. Box 5800

MS 0665

Albuquerque, NM 87185-0665 USA

Telephone: 505/845-8241

Email: rtjohns@sandia.gov

James R. Jones

U.S. Army Primary Standards Lab

Bldg. 5435

AMSMI-TMDE-S

Redstone Arsenal, AL 35898-5400

USA

Telephone: 205/876-2666

Fax: 205/842-8297

Email: jjopnes@redstone.army.mil

Barbara Judge

Compliance Consulting Services

1366 Bordeaux Dr.

Sunnyvale, CA 94089 USA

Telephone: 408/752-8166

Email: bjudge@ccsemc.com
Ryo Kamito

Standards Dept. AIST, MITI

1-3-1 Kasumigaseki

Chiyoda-ku, Tokyo, JP 100 JAP/

Christine Kearney

Mobil Oil Corp.

P.O. Box 1027

Princeton, NJ 08543-1027 USA

Telephone: 609/737-4571

Fax: 609/737-5019

Robert Kiefer

Chemical Specialties Mfg. Assoc

1913 Eye St., NW

Washington, DC 20006 USA

Telephone: 202/872-8110

Fax: 202/872-8114

Greg Kiemel

Northwest EMC, Inc.

$120 \mathrm{~S}$. Elliott Rd.

Ste. 300

Newberg, OR 97132-2134 USA

Telephone: 503/648-0275

Fax: 503/537-0735

Michael King

ITW Anchor Fasteners

26101 Fargo Ave.

Bedford Hgts., OH 44146 USA

Telephone: 216/292-7161

Fax: 216/292-0412

Frank Kitzantides

National Elect. Mfg. Assoc.

1300 N. 17th St.

Ste. 1847

Rosslyn, VA 22209 USA

Telephone: 703/841-3258

Fax: 703/841-3358 
Mark Kline

Iroemner, Inc.

8825 Greenway Ave.

hiladelphia, PA 19142 USA

Telephone: 215/724-0800

Email: triemner@troemner.com

Raymond Klouda

Elite Electronic Engineering Co.

1516 Centre Circle

Downers Grove, IL 60515 USA

relephone: $630 / 495-9770$

ax: 630/495-9785

arry Knab

NIST

3ldg. 820, Rm. 282

Zaithersburg, MD 20899-0001

SSA

lohn Kopec

Riverbank Acoustical Labs

512 Batavia Ave.

ieneva, IL 60134 USA

elephone: 630/232-0104

ax: 630/232-0138

lavid Krashes

AMR Group, Inc.

41 West Boylston St.

Vest Boylston, MA 01583 USA

elephone: 508/835-6262

ax: 508/835-9025

en Kruger

Jongressional Research Service

ibrary of Congress

Vashington, DC 20540 USA

elephone: 202/707-7070

ax: 202/707-7000

mail: Ikruger@crs.loc.gov
Richard Kuchnicki

CABO

5203 Leesburg Pike, Ste. 708

Falls Church, VA 22041 USA

Telephone: 703/931-4533

Fax: 703/379-1546

Email:kuchnicki@cabd.org

Rajendra Kumar

U.S.P.S.

8403 Lee Highway

Merrifield, VA 22082-8101 USA

Telephone: $703 / 280-7338$

William LaPreutte

Fleet Tech Support Ctr., Atlantic

928010 th Ave.

Norfolk, VA 25311-4396 USA

Telephone: 757/485-6364

Fax: 757/485-6279

Email: lapreuette_mark@

ftsc.emh.ftsclant

Maria Laudisi

IV Labs, Inc.

195 Lehigh Ave., Ste. 4

Lakewood, NJ 08701 USA

Telephone: 908/901-1900

G. Diane Lee

NIST

Bldg. 820, Rm. 223

Gaithersburg, MD 20899-0001

USA

Telephone: 301/975-4405

Fax: 301/926-0647

Email: diane.lee@nist.gov

Charles G. Leete

Collaborative Testing Services, Inc

340 Herndon Pkwy.

Herndon, VA 21070 USA

Telephone: 703/742-9107

Fax: 703/481-0375
Elizabeth Lehman

Food \& Drug Admin.

5600 Fishers Lane

Rm. 12-41, HFC-140

Rockville, MD 20857 USA

Telephone: $301 / 443-3320$

Fax: 301/443-6388

Walter Lehmus

Edmunds Gages

Spring Lane

Farmington Industrial Park

Farmington, CT 06032 USA

Telephone: 860/677-2813

Fax: 860/677-4243

Walter Leight

NIST

Bldg. 820, Rm. 282

Gaithersburg, MD 20899-0001

USA

Telephone: $301 / 975-4000$

Donald Lein

Cornell Univ./Diagnostic Lab

Box 3986

Ithaca, NY 14852-5786 USA

Telephone: 607/253-3900

Fax: 607/253-3903

Vernon Lewis

Old Dominion University

214 Kaufman Hall

Norfolk, VA 23529 USA

Telephone: 757/683-3786

Fax: 757/683-5655

Thomas Lillie

Technimet Corporation

2345 South 170 th St.

New Berlin, WI 53151 USA

Telephone: 414/782-6344

Fax: 414/782-3653 
Jerry Linn

NIST

Bldg. 820, Rm. 634

Gaithersburg, MD 20899-0001

USA

Telephone: 301/975-3624

Fax: 301/975-1784

Email: linnrj@nist.gov

John Locke

John Locke \& Associates

5181 Woods Resort

Hedgesville, WV 25427 USA

Telephone: 304/754-5905

Fax: 304/754-5906

Email: lockewv@inrepid.net

David Loebach

OSHA

435 Elm St.

Ste. 500

Cincinnati, OH 45202 USA

Telephone: 513/684-6390

Fax: 513/64-2630

Email: dloebach2osha_slc.gov

Robert Lommler

Illinois Dept. of Nuclear Safety

1301 Knotts St.

Springfiled, IL 62703 USA

Telephone: 217/786-7129

Fax:217/786-7223

Email: lommler@idns.state.il.us

Carmina Londono

NIST

Bldg. 820, Rm. 282

Gaithersburg, MD 20899-0001

USA

Telephone: 301/975-2573
Richard Lorentzen

Lucent Technologies

101 Crawfords Corner

Rm. 11C-185

Holmdel, NJ 07733-3030 USA

Telephone: 908/834-1864

Fax: 908/834-1830

Email: rplorentzen@

gpcl.lucent.com

Samual Low

NIST

Bldg. 223, Rm. B256

Gaithersburg, MD 20899-0001

USA

Telephone: 301/975-6498

John Maas

IBM

3505 Highway 52 North

Rochester, MN 55901 USA

Telephone: 507/253-2426

Fax: 507/253-1317

Email: jsmaas@vnet.ibm.com

David MacLean

6422 Alloway Ct.

Springfield, VA 22152-2801 USA

Telephone: 703/451-1578

Donald Mader

Undenwriters Labs

333 Pfingsten Rd.

Northbrook, IL 60062 USA

Telephone: 847/272-8800

Fax: 847/272-8845

Bernard Magalski

U.S. Air Force

813 Irving Wick Dr., W

Ste. 4M/AFMETCAL DET1

Heath, OH 43056-6116 USA

Telephone: 614/788-5032

Fax: 614/788-5021
Subhas Malghan

NIST

Bldg. 820, Rm. 282

Gaithersburg, MD 20899-0001

USA

Telephone: 301/975-6101

Robert Manning

Cannon Instrument $\mathrm{Co}$.

2139 High Tech. Rd.

State College, PA 16803 USA

Telephone: 814/353-8000

Fax: 814/353-8007

George Marinenko

WPI

555 Quince Orchard Rd.

Ste. 600

Gaithersburg, MD 20878-1437

USA

Telephone: 301/990-3999

Fax: 301/990-3999

Michelle Marley

MJ Reider Associates, Inc.

107 Angelica Street

Reading, PA 19611 USA

Telephone: 610/374-5129

Fax: 610/374-7234

Robert Martell

Factory Mutual Res. Corp. 1151 Boston Providence Tpk. Norwood, MA 02062 USA

Telephone: 617/255-4850

Fax: 617/762-9375

James Mattimore

Dayton T. Brown, Inc.

Church St.

Bohemia, NY 11716 USA

Telephone: 516/244-6210

Fax: 516/589-3648 
3rian Mattson

JLS Electronic Systems 1250 Peterson Dr. Wheeling, IL 60090 USA Telephone: 847/537-6400 =ax: 847/537-6488

Stephen Mawn

ASTM

100 Barr Harbor Dr.

W. Conshohcken, PA 19428 USA Telephone: $610 / 832-9726$

Fax: 610/832-9666

Email:smawn@local.astm.org

Sergio Mazza

ANSI

11 W. 42nd St., 13th Floor Vew York, NY 10036 USA Telephone: 212/642-4900 =ax:212/398-0023

Email:smazza@ansi.org

Ray McAllister

\section{ACPA}

1156 15th St., NW

Ste. 400

Nashington, DC 20005 USA

Telephone: 202/872-3874

=ax: 202/463-0474

Email: ray@acpa.org

John McDaniel

American Lumber Standards Com.

3.0. Box 210

Germantown, MD 20875 USA

Telephone: 301/972-1700

=ax: 301/340-8004
Ann Marie McNamara

USDA/FSIS

300 12th St., SW

Rm. 310

Washington, DC 20250 USA

Telephone: 202/205-0212

Fax:202/720-4662

Patricia Melerski

Abbott Labs

200 Abbott Park Rd.

MC D-49, AP31

Abbott Park, IL 60064-3537 USA

Telephone: 847/938-3717

Fax: 847/937-9616

Garry Meyer

Wiltron Co.

490 Jarvis Dr.

Morgan Hill, CA 95037 USA

Telephone: 408/778-2000

Fax: 408/778-3180

Email: gmeyer@wiltron.com

Kenny Meyn

Delta Testing

725 S. Genos St.

New Orleans, LA 70119 USA

Telephone: 504/486-5595

Fax: 504/486-5598

Jim Millette

MVA, Inc.

5500 Oakbrook Pkwy.

Ste. 200

Norcross, GA 30093 USA

Telephone: 770/662-8509

Fax: $770 / 662-8532$
Paul Moliski

ITS

3933 U.S. Rt 11

Cortland, NY 13045 USA

Telephone: 607/758-6336

Fax:607/756-6699

Juan Moore

Wavetek

1016 S. Wayne St.

MC 210

Arlington, VA 22204 USA

Telephone: 703/920-0564

Email:moorej@wavetek.com

James Moorman

Brush Wellman, Inc.

17876 St. Clair

Cleveland, OH 44110 USA

Telephone: 216/692-3022

Fax:216/481-5480

Jeanne Mourrain

U.S. EPA

NERL (MD-75)

RTP, NC 27711 USA

Telephone: 919/541-1120

Fax: 919/541-4101

Email:mourrain.jeanne@

epamail.epa.gov

Keith Mowry

Underwriters Labs

333 Pfingsten Rd.

Northbrook, IL 60062

Telephone: 847/272-8800

ext. 43894

Fax: 847/509-6219 
Richard Moyers

Philips Testing Service

One Philip Drive

P.O. Box 14810

Knoxville, TN 37918-1810 USA

Telephone: 423/521-1617

Fax: 423/521-1637

Email: basnguy@usit.net

Roy Myers

$R$ \& M Consultants, Inc.

P.O. Box 10972

St. Louis, MO 63135 USA

Telephone: 314/521-4282

David Nebel

Electronic Distributors

1458 Yankee Park Place

Ste. J

Centerville, OH 45458-1854 USA

Telephone: 937/436-1888

\section{Daphne Neel}

SC Dept. of Health \& Environ. Ctrl. 2600 Bull St.

Columbia, SC 29201 USA

Telephone: 803/935-7031

Fax: 803/935-7363

\section{Ed Nemeroff}

Wavetek

3744D SW Quail Meadow Trail

Palm City, FL 34990 USA

Telephone: 561/287-3547

Fax: 561/287-3347

Lynne Neumann

Entela

3033 Madison Ave., SE

Grand Rapids, MI 49548 USA

Telephone: 616/247-0515

Email:Ineumann@entela.com
Linda $\mathrm{Ng}$

FDA

5600 Fishers Lane

MC HFD-570

Rockville, MD 20857 USA

Telephone: 301/827-1052

Fax: 301/827-1271

Tracey Niland

Broadview Instrumentation

Services

9240 Broadview Rd.

Broadview Hgts., OH 44147 USA

Telephone: 216/526-2911

Fax: 216/526-9229

Finbarr O'Connor

R\&B Enterprises

20 Clipper Rd.

W. ConsHo Hocken, PA 19428

USA

Telephone: 610/825-1960

Fax: 610/825-1684

Email: emc@rt1tem.com

Keith O'Hanlon

Cincinnati Precision Instr.

253 Circle Freeway D

Cincinnati, OH USA

Telephone: 513/874-2122

Fax: 513/874-2536

Joe O'Neil

ACIL

1629 K St., NW

Washington, DC 20006 USA

Telephone: 202/887-5872

Fax: 202/887-0021
Anthony O'Neill

National Fire Protection Assoc.

1110 North Glebe Rd.

Ste. 560

Arlington, VA 22201 USA

Telephone: 703/516-4346

Fax: 703/516-4350

Email:wdc@nfpa.org

Ralph Obenauf

Spex Certiprep

203 Norcross Ave.

Metuchen, NJ 08840 USA

Telephone: 908/549-7144

Fax: 908/603-9647

Todd Okamura

Northrop Grumman Corp.

8900 E. Washington Blvd.

Orgn 9881/GK

Pico Rivera, CA 90660-3755 US

Telephone: 310/942-6740

Fax: 310/948-8068

Timothy Osborne

Ecology Services, Inc.

10220 Old Columbia

Columbia, MD 21046 USA

Telephone: 410/381-2600

Fax: 410/381-2602

Jean Otter

AABB

8101 Glenbrook Rd.

Bethesda, MD 20814 USA

Telephone: 301/902-6972

Fax: 301/907-6895 
Percy Pan

$A A L A$

356 Quince Orchard Rd., Ste. 620

Gaithersburg, MD 20878 USA

Telephone: 301/670-1377

-ax: 301/869-1495

Email:ppan@a2la.org

Tony Papliarv

$\mathrm{ACIL}$

629 K St., NW

Nashington, DC 20006 USA

elephone: 202/887-5872

=ax: 202/887-0021

Bernard Pasquet

SSHA

00 Constitution Ave., NW

ite. N3653

Nashington, DC 20210 USA

elephone: 202/219-7056

Richard Patterson

letecon, Inc.

2 Hixon St.

Sellingham, MA 02019 USA

elephone: 508/966-4704

ax: 508/966-4920

:mail: rp@interserv.com

Senjamin Perillo

Jug Enforcement Admin.

00 Army Navy Drive

rlington, VA 22202 USA

elephone: 202/307-8866

ax: 202/307-8851

hark Petrilla

J.S. Army TMDE Support

IMSMI-TMDE-GA

Chambersburg, PA 17201 USA

elephone: 717/267-8138
Richard Pettit

Sandia National Labs

P.O. Box 5800, MS 0665

Albuquerque, NM 87185-0665 USA

Telephone: 505/844-6242

Email: rbpetti@sandia.gov

Dale Pfriem

Intl. Certification Serv.

9337 Ravenna Rd., Ste. B-14

Twinsburg, OH 44087 USA

Telephone: 216/405-1418

Fax: 216/405-1420

Email:dpfriem@intcert.com

Kim Phillipi

ENTELA

3033 Madison Ave., SE

Grand Rapids, MI 49548 USA

Telephone: 616/247-0515

Tom Phillips

Federal Communications

Commission Lab.

7435 Oakland Mills Rd.

Columbia, MD 21046 USA

Telephone: 301/725-1585

ext. 218

Fax: 301/344-2050

Email: tphillip@fcc.gov

James Pielert

NIST

Bldg. 226, Rm. A365

Gaithersburg, MD 20899-0001

USA

Telephone: 301/975-6704

Fax: 301/330-1956
Michael Pinagel

Michigan Dept. of Ag.

P.O. Box 30017

Lansing, MI 48909 USA

Telephone: 517/373-1060

Fax: 517/373-3333

Email: pinegelm@state.mi.us

Tim Pline

The Cold Heading Company

21777 Hoover Rd.

Warren, Ml 48089 USA

Telephone: 810/497-7015

Fax: 810/497-7069

Thomas Powis

Broadview Instrumentation

Services

9240 Broadview Rd.

Broadview Hgts., OH 44147 USA

Telephone: 216/526-2911

Fax: 216/526-9229

Lawrence A. Presley

FBI Laboratory

FBI Academy

Rm. 322, FSRTC

Quantico, VA 22135 USA

Telephone: 703/640-1113

Fax: 703/640-1491

William Pryor

Dyn McDemott

250 S. Clearview Pkwy., MC EF-86

New Orleans, LA 70123 USA

Telephone: 504/734-4699

Fax: 504/734-4192

Francis Ptak

Gascoyne Laboratories

2101 Van Deman St.

Baltimore, MD 21224 USA

Telephone: 410/633-1800

Fax: 410/633-6553 
Debra Rade

Underwriters Labs

333 Pfingsten Rd.

Northbrook, IL 60062 USA

Telephone: 847/272-8800

Fax: 847/272-88862

Michael Rafalowski

FDA

4007 th St., SW

MC HNG 23

Washington, DC 20590 USA

Telephone: 202/366-1571

Fax: 202/366-1571

Email:michael.rafalowski@

fhwa.dot.gov

C.P. Ramani

ICBO Evaluation Services

5360 Workman Mill Rd.

Whittier, CA 90601 USA

Telephone: 310/699-0543

Fax: 310/695-4694

Ralph Randall

FDA

800 Independence Ave., SW

Washington, DC 20591 USA

Telephone: 202/267-8903

Fax: 202/267-9713

Email: ralph.randall@faa.dot.gov

Robert Ranzenbach

GLM Wind Tunnel

Univ. of MD

Bldg. 081

College Park, MD 20742 USA

Telephone: 301/405-6871

Fax: $301 / 314-9628$
Ira Reese

U.S. Customs Service

1301 Constitution Ave., NW

MS 7113

Washington, DC 20229 USA

Telephone: 202/927-1060

Fax: 202/927-2067

Allen Reeves

Architectural Testing

130 Derry Court

York, PA 17019 USA

Telephone: 717/764-7700

Fax: 717/764-4129

Sally Remedios

Delta Faucet Co.

$55 \mathrm{E} 111$ th St.

P.O. Box 40980

Indianapolis, IN 46280 USA

Telephone: 317/587-1270

Fax: 317/848-0750

Email: sar@deltafaucet.com

Roger Rensberger

NIST

Bldg. 820, Rm. 282

Gaithersburg, MD 20899-0001

USA

Telephone: 301/975-2766

Myron Rhodes

Food \& Drug Admin.

1114 Market St., Rm. 1002

St. Louis, MO 63101 USA

Telephone: 314/539-2011

Fax: 314/539-2113

Hazel Richmond

NIST

Bldg. 820, Rm. 282

Gaithersburg, MD 20899-0001

USA

Telephone: 301/975-3024
James E. Riley

Atlas Testing Labs, Inc.

6929 E. Slavson Ave.

Los Angeles, CA 90040 USA

Telephone: 213/722-8810

Fax:213/888-1493

Gerald Ritterbusch

Caterpillar, Inc.

217 S. Baltimore Ave.

Morton, IL 61550-2423 USA

Telephone: 309/675-5287

Fax: 309/675-6181

Email: ritterbusch_gerald_h

Roxanne Robinson

AALA

656 Quince Orchard Rd., Ste. 6 c

Gaithersburg, MD 20878 USA

Telephone: 301/670-1377

Fax: 301/69-1495

Email: rrobinson@a2la.org

Gregory Rosasco

NIST

Bldg. 221, Rm. B312

Gaithersburg, MD 20899-0001

USA

Telephone: 301/975-2609

Fax: 301/869-5924

Lannie Rowe

American Electric Power

1 Riverside Plaza

Columbus, OH 43215 USA

Telephone: 614/836-4214

Fax: 614/836-4168

Patricia Royal

Springborn Labs, Inc.

790 Main St.

Wareham, MA 02571 USA

Telephone: 505/295-2550

Fax: 505/295-8107 
James T. Rucker ockheed Martin NASA Johnson Space Ctr. US ND615 touston, TX 77058 USA Telephone: 281/483-0270

James Ruggieri

J.S. Coast Guard

2100 2nd St., SW

im. 1300, MSE 3

Nashington, DC 20593 USA

relephone: 202/267-0028

Kevin Ruhl

TRW

One Space Park

USS/2470

Redondo Beach, CA 90278 USA

relephone: 310/812-1430

-ax: 310/814-8797

Email:kevin.ruhl@trw.com

Ramona Saar

AALA

356 Quince Orchard Rd.

Ste. 620

Gaithersburg, MD 20878 USA

Telephone: 301/670-1377

=ax: 301/869-1495

Email: rsaar@a2la.org

Teorge Sauer

Ramco Specialties, Inc.

3369 Hudson Dr.

tudson, OH 44236-3777 USA

Telephone: 216/653-5135

=ax: 216/650-5326
Paul Schlecht

N.I.O.S.H.

4676 Columbia Pkwy.

MS R-8

Cincinnati, OH 45226 USA

Telephone: 513/841-4266

Fax: 513/841-4545

Harvey Schock

Product Assurances System

309 Bridgebord Rd.

MC 1464

Mooretown, NJ 08057-1425 USA

Telephone: 609/222-9050

Fax: 609/222-9050

Morton Schwartz

U.S. Dept of Energy

20030 Century Blvd.

Bldg. III, Rm. 317

Germantown, MD 20874 USA

Telephone: 301/903-2996

Fax: 301/9032-4594

Email:norm.schwart@@hq.doe.gov

Shirish Shah

Compatible Electronics, Inc.

114 Olinda Dr.

Brea, CA 99823 USA

Telephone: 714/579-0500

Fax: $714 / 579-1850$

Michael Sickmiller

AGA Gas, Inc.

6421 Monclova Rd.

Maumee, OH 43537 USA

Telephone: 419/893-7226

Fax: 419/893-6411
Charles Silver

Charles C. Kawin Co.

2671 Gardner

Broadview, IL 60153 USA

Telephone: 708/865-0400

Fax: 708/865-1618

Thomas Slowey

K \& S Associates, Inc.

1926 Elm Tree Dr.

Nashville, TN 37210 USA

Telephone: 615/883-9760

Fax: 615/871-0856

Email:tslowey@kslab.com

Dennis Smith

AMP, Inc.

P.O. Box 3608

MS 210-020

Harrisburg, PA 17105-3608 USA

Telephone: 717/592-6278

Fax: 717/592-6179

Email:desmith@amp.com

Douglas Smith

Abbott Labs

1401 Sheridan Rd.

N. Chicago, IL 60064 USA

Telephone: 847/937-4929

Fax: 847/937-4634

James Smith

GE Capital TMS

1062 Tower Lane

Bensenville, IL 60106 USA

Telephone: 630/595-4343

Fax: 630/595-3675 
John Smith

NIST

Bldg. 223, Rm. B254

Gaithersburg, MD 20899-0001

USA

Telephone: 301/975-6498

Fax: 301/975-4553

Email:jhsmith@nist.com

Peter Spellerberg

NIST/AMRL

Bldg. 226, Rm. A365

Gaithersburg, MD 20899-0001

USA

Telephone: 301/975-6704

Fax: 301/330-1956

Email:pspell@nist.gov

Troy Stallard

Standard Labs, Inc.

14711 th Ave.

Ste. 100

S. Charleston, WV 25303 USA

Telephone: 304/744-6800

Fax: 304/744-6899

Joan Sterling

ITS/Inchape

1325 13th St., NW

Ste. 6

Washington, DC 20005 USA

Telephone: 202/265-3378

Fax: 202/265-0687

Email:js@itsqs.com

S. Wayne Stiefel

NIST

Bldg. 820, Rm. 282

Gaithersburg, MD 20899-0001

USA

Telephone: 301/975-4011
Keith Swinehart

VANGUARD Piping Systems, Inc.

2966 Trask Pkwy.

Beaufort, SC 29902 USA

Telephone: 803/846-2172

Fax: 803/846-2089

Larry Tarr

U.S. Army Primary Standards Lab

Bldg. 5435

AMSMI-TMDE-SE

Redstone Arsenal, AL 35898-5400

USA

Telephone: 205/876-8471

Fax: 205/876-6014

Email: Itarr@redstone.army.mil

Gene Tatsch

RTI

P.O. Box 12194

RTP, NC 27709 USA

Telephone: 919/541-6830

Fax: 919/544-7529

Email:mltatsch@aol.com

Mary Lou Tatsch

ML Solutions

5911 Grandale Drive

Durham, NC 27713 USA

Telephone: 919/544-7529

Gary Tyra

TUV Rheinland Of NA, Inc.

12 Commerce Rd.

Newton, CT 06470 USA

Telephone: 203/426-0888

Fax: 203/270-8883
Peter Unger

AALA

565 Quince Orchard Rd.

Ste. 620

Gaithersburg, MD 20878 USA

Telephone: 301/670-1377

Fax: 301/869-1495

Email:punger@a2la.org

Pamela Usatch

Acts Testing Labs, Inc.

25 Anderson Rd.

Buffalo, NY 14225 USA

Telephone: 716/897-3300

Mouli Vaidyanthan

Schevers Labs

6499 Rhine Rd.

P.O. Drawer 9

Watertown, WI 53094 USA

Telephone: 800/216-9474

Fax: 414/261-9453

Email:moul@castlab.cngr.wisc.

Len Valenti

Food \& Drug Admin.

5600 Fishers Lane

Rm. 12-41, HFC 141

Rockville, MD 20857 USA

Telephone: 301/443-3320

Fax: 301/443-6388

Daren Valentine

AALA

656 Quince Orchard Rd.

Ste. 620

Gaithersburg, MD 20878 USA

Telephone: 301/670-1377

Fax: 301/869-1495

Email:dvalentine@a2la.org 
licky Van Meter Vavetek Corporation 045 Balboa Ave.

ian Diego, CA 92123 USA elephone: 619/279-2955 ax: 619/627-0130 mail:vanmeterv@wavetek.com

liue Van Orden

OT/NHTSA

00 7th Street, SW

im. 6111

Vashington, DC 20590 USA

elephone: 202/366-5311

ax: 202/366-1024

lalph Veale

IIST

idg. 220, Rm. B113

kaithersburg, MD 20899-0001

ISA

elephone: 301/975-3502

mail: rcveale@aol.com

Ihristian Vrolijk

lorthrop Grumman Corp.

900 E. Washington Blvd.

rgn 9881/GK

ico Rivera, CA 90660-3755 USA

elephone: $310 / 948-6218$

ax: 310/948-8068

Villiam Wagner

erformance Review Inst.

61 Thornhill Rd.

Varrendale, PA 15086 USA

elephone: 412/772-1616

ax: 412/772-1699

mail:wagner@sae.org
Barry Wallen

Infellistor Oats

1350 County Rd. \#16

P.O. Box 387

Rollinsville, CO 80474 USA

Telephone: 303/682-6600

Fax: 303/682-6672

Email: bwallen@intellisfor.com

George Walton

AMECA

1101 15th St., NW

Ste. 607

Washington, DC 20005 USA

Telephone: 202/898-0145

Fax: 202/898-0148

Gan Wang

Amtek Inc., US Gauge Div.

8600 Somerset Dr.

Largo, FL 33773 USA

Telephone: 813/536-7831

Fax: 813/532-3335

Nancy Ward

Cotton Incorporated

4505 Creedmoor Rd.

Textile Services Lab

Raleigh, NC 27612 USA

Telephone: 919/510-6117

Fax: 919/881-9874

Chad Warrington

Caterpillar, Inc.

P.O. Box 1875

MC TC-K

Peoria, IL 61656-1875 USA

Telephone: 309/578-2852

Fax: 309/578-4491

Email:warries@cat.com
Stanely Warshaw

NIST

Bldg. 820, Rm. 326

Gaithersburg, MD 20899-0001

USA

Telephone: 301/975-4193

Fax: 301/975-2183

Email: stanley.warshaw@nist.gov

Bob Wayland

Sandia National Labs

P.O. Box 5800

MS 1367

Albuquerque, NM 87185 USA

Telephone: 505/271-7917

Fax: 505/271-7975

Vanda White

NIST

Bldg. 820, Rm. 282

Gaithersburg, MD 20899-0001

USA

Telephone: 301/975-3592

Thomas Wiand

Hart Scientific

799 E. Utah Valley Dr.

American Fork, UT 84003-9775

USA

Telephone: 801/763-1600

Fax: 801/763-1010

Torleie Wiik

U.S. Postal Service

495 L'Enfant Plaza

Rm. 443

Washington, DC 20260-6204 USA

Telephone: 202/268-2108 
Herbert Wilgis

Penniman \& Browne, Inc.

6252 Falls Rd.

Baltimore, MD 21209 USA

Telephone: 410/825-4131

Fax: 410/321-7384

Matt Williams

NEMA

1300 N. 17th St.

Rosslyn, VA 22205 USA

Telephone: 703/841-3297

Fax: 703/841-3397

Email:mat_williams@nema.org

George Willinmgyre

GTW Assoc.

1012 Parrs Ridge Dr.

Spencerville, MD 20868 USA

Telephone: 301/421-4138

Fax: 301/421-0977

Email:gtw@gtwassociates.com

Joanne Wilson

Lucent Technologies

900 19th St.

Ste. 700

Washington, DC 20006 USA

Telephone: 202/530-7024

Fax: 202/530-7007

Email:jcwilson@lucent.com

Mark Wirtz

FDA

200 C St., SW

MC HFS-337

Washington, DC 20204 USA

Telephone: 202/205-5138

Fax: 202/205-4422

Email:msw@fdacf.ssw.dhhs.gov
Sandra Wroblewski

Kemper/NATLSCO

1 Kemper Dr.

MS K2

Long Grove, IL 60049 USA

Telephone: 847/320-2487

Fax: 847/320-4331

Chang-Yu Wu

IBM

522 South Rd.

MC P355

Poughkeepsie, NY 12590 USA

Telephone: 914/435-1822

Fax: 914/432-9831

Email:chang-uyw@vnet.ibm.com

Frank Wu

Taipei Econ. \& Culture Rep. Office

4301 Connecticut Ave., NW

MS 420

Washington, DC 20008 USA

Telephone: 202/686-6400

Fax: 202/363-6294

James Yager

Food \& Drug Admin.

5600 Fishers Lane

Rm. 12-41, HFC-140

Rockville, MD 20857 USA

Telephone: 301/443-3320

Fax: 301/443-6388

Michael Yakubick

Product Test Ctr.

Defense Logistics Agy.

Bldg. 1-8

New Cumberland, PA 17070 USA

Telephone: 717/770-4098

Fax: $717 / 770-5042$
Simone L. Yaniv

NIST

Bldg. 233, Rm. B108

Gaithersburg, MD 20899-0001

USA

Telephone: $301 / 975-4851$

Fax: 301/869-3536 
APPENDIX D

NACLA Interim Board of Directors

(Selected February 19, 1997) 



\section{Interim Board of Directors for the \\ National Council for Laboratory Accreditation (NACLA)}

On February 19, 1997, the Laboratory Accreditation Working Group (LAWG) Steering Committee met to elect the NACLA Interim Board of Directors. In accordance with recommendations made by the Nominating Committee, the Steering Committee agreed that:
$>\quad$ The number of Government representatives should be increased from four to five.
$>\quad$ The number of Accrediting Bodies representatives should be increased from three to four.
$>\quad$ The name of the General Interest category should be changed to "Members at Large."
$>\quad$ NIST should continue to serve as the Interim Secretariat for the NACLA Interim Board of Directors.

The Committee further agreed to the following membership for the NACLA Interim Board of Directors:

\section{Chair}

Belinda L. Collins, Director

Office of Standards Services

National Institute of Standards and Technology

Building 810, Room 282

National Institute of Standards and Technology (NIST)

Gaithersburg, MD 20899

Phone: (301) 975-4000 Fax: (301) 963-2871

E-Mail: belinda.collins@nist.gov

Dr. Collins, a co-chair of the Laboratory Accreditation Working Group (LAWG), chairs the Interagency Committee on Standards Policy (ICSP) and serves on the boards and councils of several major standards developing organizations. Her office is responsible for implementing the Technology Transfer and Advancement Act with respect to coordinating standards and conformity assessment activities within government and with the private sector. 
Government Representatives

Linda Horton, JD, Director

International Policy

Office of Policy

Food and Drug Administration

5600 Fisher's Lane, Room 15-74 (HF - 23)

Rockville, MD 20857

Phone: (301) 827-3344 Fax: (301) 443-6906

E-Mail: Ihorton@bangate.fda.gov

Ms Horton serves as the Standards Executive for the Food and Drug Administration (FDA) of the Department of Health and Human Services and sits on the ICSP. She has responsibility for all FDA matters pertaining to domestic and international standards issues and policies.

Julius Knapp

Federal Communications Commission

7435 Oakland Mills Road

Columbia, MD 21046

Phone: (301) 725-1585 Fax: (301) 344-2050

E-Mail: jknapp@fcc.gov

Mr. Knapp, Chief of the FCC Equipment Authorization Division, authorizes telecommunications and electronic equipment to ensure compatibility with FCC technical standards for controlling radio frequency interference. These procedures entail use of accredited test laboratories, a field in which Mr. Knapp has been active, both domestically and with respect to international conformity assessment matters, including MRA negotiations with the European Union.

Michael J. Luwe

Naval Warfare Assessment Division

Measurement Science Directorate

P.O. Box 5000

Corona, CA 91718-5000

Phone: (909) 273-5221 Fax: (909) 273-5446

E-Mail: luwe.michael@corona.navy.mil

Mr. Luwe is Associate Director of the Directorate and has linkages to Joint Service/DOD metrology programs and DOD contractors and laboratories, including the application of laboratory accreditation.

Richard B. Pettit

Sandia National Laboratories

Mail Stop 0665, P.O. Box 5800

Albuquerque, NM 87185-0665

Phone: (505) 844-6242 Fax: (505) 844-4372

E-Mail: rbpetti@sandia.gov 
Dr. Pettit is manager of the Primary Electrical Standards Laboratory at Sandia, responsible for the electrical standards and calibration program for the Department of Energy (DOE). He serves on the DOE steering committees responsible for initiatives in metrology and accreditation and is also Chairman of the National Conference of Standards Laboratories (NCSL) committee on Intrinsic/Derived Standards.

\section{Michael Rafalowski}

Federal Highway Administration

400 Seventh St. SW, HNG-23

Washington, D.C. 20590

Phone: (202) 366-1571 Fax: (202) 366-9981

E-Mail: michael.rafalowski@fhwa.dot.gov

As Leader of the Materials Group, Mr. Rafalowski is responsible for agency policies and guidance in materials sampling and testing. He developed the regulations used for accrediting laboratories that perform particular functions.

\section{Industry Representatives}

Louis T. Dixon, Ph.D.

Ford Motor Company

330 Town Center Drive, Suite $700 \mathrm{C}$

Dearborn, MI 48126

Phone: (313) 337-3800 Fax: (313) 390-6327

E-Mail: Idixon@ford.com

Dr. Dixon, Manager of Body and Chassis Standards in Ford's Automotive Safety and Engineering Standards Office, is responsible for internal processes, test methods, standards and specifications for vehicles, components, and materials, as well as the company's interface for ISO and European (CEN) standards and conformity assessment issues. He was co-chair of the LAWG industry group.

\section{Donald N. Heirman}

Lucent Technologies/Bell Labs Innovations

101 Crawfords Corner Road, M/S 11C-165

Holmdel, NJ 07733

Phone: (908) 834-1801 Fax: (908) 834-1807

E-Mail: dnheirman@gpcl.lucent.com

Mr. Heirman is the manager of Lucent's global product compliance laboratory, with emphasis on telecommunications and information technology products. An internationally recognized expert and leader in EMC measurements, he is an elected member of the IEEE Standards Board, ANSI Accredited Standards Committee C63 (for EMC), and several other domestic and international committees. 
Robert C. Peck, JD, ClH

Schering-Plough

1095 Morris Ave.

Union, NJ 07083

Phone: (908) 629-3483 Fax: (908) 629-3412

E-mail: robert.peck@spcorp.com

As Director of Safety and Industrial Hygiene for Schering-Plough Corporate, Mr. Peck has world-wide responsibility for industrial hygiene monitoring and a strong interest in the laboratory accreditation programs that support this work. He has participated in the development of industrial hygiene, asbestos abatement, and environmental lead accreditation programs as a committee member, committee chair, and member of the American Industrial Hygiene Association (AlHA) Board of Directors.

Gerald H. Ritterbusch

Caterpillar Inc.

100 N.E. Adams St.

Peoria, IL 61629-7150

Phone: (309) 675-5287 Fax: (309) 675-6181

E-Mail: ritterbusch_gerald_h@cat.com

Mr. Ritterbusch's corporate responsibilities include conformity assessment for all company products, working with laboratories around the world. He served on the National Research Council committee that developed the recommendations in it report on standards and conformity assessment, especially the need for synergy in laboratory accreditation.

\section{Laboratory Representatives}

Anthony Anderson

Guildline Instruments

103 Commerce St., Suite 160

Lake Mary, FL 32746

Phone: (407) 333-3327 Fax: (407) 333-3309

E-Mail: TAnders@worldnet.att.net

Mr. Anderson was the 1996 President of the National Conference of Standards Laboratories (NCSL) and is the President and CEO of Guildline Instruments, a manufacturer of standards and calibration instruments and a provider of calibration services. He has had extensive experience in calibration, testing, and measurements and in the subject of technical barriers to trade.

James G. Kendzel

NSF International

3745 Plymouth Road

Ann Arbor, MI 48105

Phone: (313) 769-5184 Fax: (313) 769-0109

E-Mail: kendzel@nsf.org 
Mr. Kendzel is Senior Director Corporate QA of the NSF International, responsible for maintaining all NSF accreditations, including state certifications for drinking water analysis, building code body accreditations, and accreditations by ANSI and the Dutch Council of Accreditations (RvA). He serves on the ANSI accreditation Committee and on the ICBO ES Advisory Council on Accreditation.

Dave Krashes

ACIL Representative

MMR Group, Inc.

241 West Boylston St.

West Boylston, MA 01583

Phone (508) 835-6262 Fax: (508) 835-9025

E-Mail: None

Mr. Krashes founded and since 1962 has built a group of multi-accredited independent laboratories. He has been a member of ASTM E-36, Committee on Accreditation, and an active member of LAWG.

Lynne Neumann

ACIL Representative

Entela, Inc.

3033 Madison Ave SE

Grand Rapids, MI 49548

Phone: (616) 247-0515 Fax: (616) 247-7527

E-Mail: Ineumann@entela.com

Ms. Neumann has 20 years of experience in QA and ten in laboratory quality assurance, all in accredited laboratories. She is a member of the working group for the revision of ISO Guide 25 , an active participant in ILAC, a member of the A2LA Board, chair of the ACIL Accreditation Committee, and an active participant in LAWG.

\section{Accrediting Bodies}

Fred Grunder, $\mathrm{CIH}$

American Industrial Hygiene Association

2700 Prosperity Avenue, Suite 250

Fairfax, VA 22031-4320

Phone: (703) 849-8888 Fax: (703) 207-3561

E-Mail: FGRUNDER@aiha.org

Mr. Grunder is Manager of AlHA's Laboratory Accreditation Programs and a member of the ANSI task force that instigated the formation of LAWG, in which he has been an active participant. He is also active in NELAC. In the past, he has directed accredited laboratories and has served on many committees, including two laboratory accreditation committees. He is a member of ASTM, ACS, AAIH, CESSE, and an AIHA Fellow. 


\section{C.P. (Chuck) Ramani}

ICBO Evaluation Service, Inc.

5360 Workman Mill Road

Whittier, CA 90601

Phone: (562) 699-0543 Fax: (562) 695-4694

E-Mail: es@icbo.org

Mr. Ramani is Administrator of the ICBO ES laboratory accreditation program and Chairman, ICBO ES Advisory Council on accreditation. He is a member of the APLAC MRA committee and the ASTM E5 and \# 36 committees and has previously managed a consumer product testing laboratory, as well as having audited testing agencies in the United States and abroad.

\section{Peter Unger}

President, A2LA

656 Quince Orchard Rd., \#620

Gaithersburg, MD 20878-1409

Phone: (301) 670-1377 Fax: (301) 869-1495

E-Mail: punger@a2la.org

Mr. Unger is President of a diversified private sector accrediting body with prior experience in government, including NVLAP. He has been active in ILAC and in developing Mutual Recognition Agreements with national and regional accrediting bodies and an active participant in LAWG.

William G. Wagner

Performance Review Institute

161 Thornhill Rd.

Warrendale, PA 15086-7527

Phone: (412) 772-1616 Fax: (412) 772-1699

E-Mail: wagner@sae.org

Mr. Wagner is Managing Director of PRI, with responsibility for the National Aerospace Defense Contractor Accreditation Program (NADCAP).

Members At-Large

John L. Donaldson

ANSI

65515 th St. NW, Suite 300

Washington, D.C. 20005

Phone: (202) 639-4191 Fax: (202) 628-1886

E-Mail: jdonalds@ansi.org

Mr. Donaldson is a Vice President of ANSI, responsible for conformity assessment. He was formerly the Chief of the NIST NVLAP Program, Head of the U.S. delegation to ILAC and a member of the ILAC Executive Committee, member of the ISO Guide 58 Working Group, and one of the co-chairs of LAWG. 
Doug Geralde

Canadian Standards Association (CSA)

178 Rexdale Blvd

Etobicoke, Ontario, Canada

Phone: (416) 747-4295 Fax: (416) 747-4287

E-Mail: geralded@csa.ca

Mr. Geralde is a Lead Auditor for ISO 9000 in Asia, North America, and Europe; member of the Executive Board of Director International Association of Electrical Inspectors; Manager of Audits and Investigations for Coordination of Corrective Action Policies and Practices; QA Manager of the CSA Certification Division; and has extensive experience with laboratories and accreditation bodies in the United States and many other countries. 


